\title{
Leukemia inhibitory factor modulates the peripheral immune response in a rat model of emergent large vessel occlusion
}

\author{
Stephanie M. Davis ${ }^{1}$, Lisa A. Collier ${ }^{1}$, Edric D. Winford ${ }^{2}$, Christopher C. Leonardo ${ }^{5}$, Craig T. Ajmo Jr ${ }^{5}$,
} Elspeth A. Foran ${ }^{6}$, Timothy J. Kopper ${ }^{3,4}$, John C. Gensel ${ }^{3,4}$ and Keith R. Pennypacker ${ }^{1,2^{*}}$ (D)

\begin{abstract}
Background: The migration of peripheral immune cells and splenocytes to the ischemic brain is one of the major causes of delayed neuroinflammation after permanent large vessel stroke. Other groups have demonstrated that leukemia inhibitory factor (LIF), a cytokine that promotes neural cell survival through upregulation of antioxidant enzymes, promotes an anti-inflammatory phenotype in several types of immune cells. The goal of this study was to determine whether LIF treatment modulates the peripheral immune response after stroke.

Methods: Young male (3 month) Sprague-Dawley rats underwent sham surgery or permanent middle cerebral artery occlusion (MCAO). Animals were administered LIF $(125 \mu \mathrm{g} / \mathrm{kg})$ or PBS at 6, 24, and $48 \mathrm{~h}$ prior to euthanization at $72 \mathrm{~h}$. Bone marrow-derived macrophages were treated with LIF $(20 \mathrm{ng} / \mathrm{ml})$ or PBS after stimulation with interferon gamma + LPS. Western blot was used to measure protein levels of CD11b, IL-12, interferon inducible protein-10, CD3, and the LIF receptor in spleen and brain tissue. ELISA was used to measure IL-10, IL-12, and interferon gamma. Isolectin was used to label activated immune cells in brain tissue sections. Statistical analysis was performed using one-way ANOVA and Student's $t$ test. A Kruskal-Wallis test followed by Bonferroni-corrected Mann-Whitney tests was performed if data did not pass the D'Agostino-Pearson normality test.

Results: LIF-treated rats showed significantly lower levels of the LIF receptor and interferon gamma in the spleen and CD11b levels in the brain compared to their PBS-treated counterparts. Fluorescence from isolectin-binding immune cells was more prominent in the ipsilateral cortex and striatum after PBS treatment compared to LIF treatment. MCAO + LIF significantly decreased splenic levels of CD11b and CD3 compared to sham surgery. MCAO + PBS treatment significantly elevated splenic levels of interferon inducible protein-10 at $72 \mathrm{~h}$ after MCAO, while LIF treatment after MCAO returned interferon inducible protein 10 to sham levels. LIF administration with interferon gamma + LPS significantly reduced the IL-12/IL-10 production ratio compared to macrophages treated with interferon gamma + LPS alone.
\end{abstract}

Conclusions: These data demonstrate that LIF promotes anti-inflammatory signaling through alterations of the IL-12/interferon gamma/interferon inducible protein 10 pathway.

Keywords: Stroke, Inflammation, Macrophages, Ischemia, Cytokines

\footnotetext{
* Correspondence: keith.pennypacker@uky.edu

'Department of Neurology, University of Kentucky, 741 S. Limestone BBSRB

B457, Lexington, KY 40536-0905, USA

${ }^{2}$ Department of Neuroscience, University of Kentucky, 800 Rose St. Lexington,

Lexington, KY 40536, USA

Full list of author information is available at the end of the article
}

(c) The Author(s). 2018 Open Access This article is distributed under the terms of the Creative Commons Attribution 4.0 International License (http://creativecommons.org/licenses/by/4.0/), which permits unrestricted use, distribution, and reproduction in any medium, provided you give appropriate credit to the original author(s) and the source, provide a link to the Creative Commons license, and indicate if changes were made. The Creative Commons Public Domain Dedication waiver (http://creativecommons.org/publicdomain/zero/1.0/) applies to the data made available in this article, unless otherwise stated. 


\section{Background}

Permanent occlusion of the brain's major arteries, also known as emergent large vessel occlusion (ELVO), is one of the deadliest types of acute ischemic stroke and a major cause of adult disability [1-3]. Due to the size of the thrombus creating the blockage, ELVO patients are often resistant to treatment with tissue plasminogen activator (tPA), the only FDA-approved drug for the treatment of stroke. The increased use of stent retrievers for performing endovascular thrombectomy has allowed for restoration of cerebral blood flow up to $24 \mathrm{~h}$ after the onset of symptoms [4-6]. However, patients who are deemed ineligible for endovascular thrombectomy are left without sufficient treatment options [7]. Our laboratory has examined the inflammatory response to stroke using the permanent middle cerebral artery occlusion, which simulates ELVO.

Although neural cell death during large-vessel stroke is commonly associated with energy failure and low levels of oxygen, resulting brain damage occurs during two distinct phases of cellular damage. The acute cytotoxicity phase, which occurs minutes to hours after the onset of stroke, results in the death of cells within the ischemic core. The second phase of brain damage begins approximately $12-24 \mathrm{~h}$ after the onset of focal cerebral ischemia and results from systemic activation of the peripheral immune system $[8,9]$. Within the ischemic brain, dying neurons and glia release compounds such as ATP, fractalkine, or other danger-associated molecular patterns, which activate microglia, the resident macrophagelike immune cells in the brain [10-13]. Once activated, microglia damage the blood-brain barrier via the release of pro-inflammatory cytokines and matrix metalloproteinases [14].

Increased permeability of the blood-brain barrier contributes to cerebral edema and renders cells in the parenchyma vulnerable to invading peripheral immune cells. These immune cells infiltrate the brain approximately $48 \mathrm{~h}$ after cerebral ischemia and include monocytes/ macrophages, lymphocytes, and neutrophils [15-17]. Although certain populations of these immune cells, such as anti-inflammatory macrophages/microglia, may play a crucial role in phagocytosis and tissue repair, pro-inflammatory leukocytes potentiate further damage in the area surrounding the ischemic core (penumbra). In addition, peripheral $\mathrm{B}$ and $\mathrm{T}$ cells that are exposed to CNS-specific antigens may contribute towards the post-stroke adaptive immune response by antibody secretion or direct cytotoxicity $[18,19]$. This secondary phase continues until approximately $96 \mathrm{~h}$ after the onset of stroke, when the infarct reaches its maximum volume [20,21].

Of the peripheral immune cell populations that migrate to the brain after stroke, a substantial portion of them originate in the spleen. After stroke, elevated levels of norepinephrine and epinephrine mediate splenic contraction through the activation of $\alpha$ - and $\beta$-adrenoreceptors in the white pulp, where splenic leukocytes reside [22, 23]. These leukocytes are released into the peripheral circulation, although the secretion of pro-inflammatory mediators causes these cells to migrate towards the injured hemisphere and amplify the inflammatory response in the brain. Previous studies revealed inverse relationships between post-stroke spleen weights and infract volumes in addition to spleen weights and splenic CD8+ cytotoxic T cell count. These findings show that greater splenic atrophy is the result of more infiltrating immune cells, which mediate delayed neurodegeneration [24-27]. Our lab previously demonstrated that splenectomy 2 weeks prior to permanent middle cerebral artery occlusion (MCAO) had significantly increased infarct volumes after stroke [26]. Interferon gamma (IFNY) production by $\mathrm{T}$ cells and natural killer (NK) cells and subsequent induction of interferon inducible protein 10 (IP-10) triggers the first step in the delayed inflammatory response [26, 28-30]. Clinical data have shown that this post-stroke splenic response not only occurs in human stroke patients, but also differs among patients of different ages and racial backgrounds [31-33].

Leukemia inhibitory factor (LIF) is a cytokine in the IL-6 family that promotes survival of neurons and glia in several animal models of neurodegenerative disease, such as amyotrophic lateral sclerosis [34, 35], multiple sclerosis [36-42], spinal cord injury [43, 44], and stroke [45-47]. Our laboratory has identified several cytoprotective mechanisms of LIF, which include the upregulation of antioxidant enzymes peroxiredoxin IV and metallothionein III in oligodendrocytes [46, 48] and superoxide dismutase 3 in neurons [47]. Other groups have shown that in the efficacy of LIF in treating animal models of neurodegenerative disease may lie in its ability to modulate the immune system in addition to its pro-survival signaling [42, 49].

Several groups have reported that LIF alters the phenotype of macrophages/microglia from a pro-inflammatory to an anti-inflammatory phenotype. While pro-inflammatory macrophages worsen tissue damage during stroke via the release of pro-inflammatory mediators (tumor necrosis factor- $\alpha$, IL-12, IL-6, IL-1 $\beta$, nitric oxide, etc.), anti-inflammatory cells are primarily phagocytic and release anti-inflammatory mediators. In addition, these macrophages/microglia recruit other anti-inflammatory cells such as CD4+CCR4+ helper T lymphocytes and regulatory $\mathrm{T}$ cells (Tregs) to the site of injury. Duluc et al. demonstrated that LIF and IL-6, in conjunction with macrophage colony-stimulating factor cause monocytes to differentiate into IL- $12^{\text {low }} \mathrm{IL}-10^{\text {high }}$ tumor-associated macrophages, a specialized class of anti-inflammatory leukocytes that protect cancerous growths from NK cells [50]. 
Although pro-inflammatory macrophages/microglia further damage neural cells after stroke by perpetuating inflammation and producing reactive oxygen species, macrophages/microglia with an anti-inflammatory phenotype contribute to the repair process during ischemia $[13,51]$. Therefore, LIF may indirectly reduce the neuroinflammation-associated damage during stroke by increasing the population of anti-inflammatory macrophages/microglia.

Previously, we showed that LIF reduces tissue damage and improves function recovery after stroke through the Akt-dependent upregulation of antioxidant enzymes in neurons and oligodendrocytes [46, 47]. The purpose of this study is to determine whether LIF alters the post-stroke splenic response by changing the phenotype of macrophages/microglia from a pro-inflammatory to an anti-inflammatory phenotype.

\section{Methods}

\section{Animal care}

Animal procedures were pre-approved by the Institutional Animal Care and Use Committee at the University of South Florida and performed according to the NIH Guide for the Care and Use of Laboratory Animals. Power analysis was used to determine the appropriate number of animals for each experiment. Sprague-Dawley rats were purchased from Envigo (Indianapolis, IN, USA). C57BL/6 mice were purchased from Jackson Laboratories (Bar Harbor, ME, USA). Animals were maintained on a 12-h light-dark cycle (07:00-19:00 h) in a climate-controlled room and allowed access to food and water ad libitum. In vivo procedures were performed on young (3 months), male rats weighing between 300 and $350 \mathrm{~g}$. For in vitro experiments, bone marrow was harvested from young mice (2-3 months).

\section{Middle cerebral artery occlusion}

Permanent focal cerebral ischemia was induced using the intraluminal middle cerebral artery occlusion (MCAO) model as previously described [52]. A 40-mm monofilament was introduced through the ligated external carotid artery and advanced through the internal carotid artery. The filament was advanced until it reached the origin of the middle cerebral artery. Reduction in cerebral blood flow was confirmed using Laser Doppler (Moore Lab Instruments, Farmington, $\mathrm{CT}$ ). Only animals experiencing $\geq 60 \%$ reduction in cerebral perfusion were included in the study. Animals subjected to the sham MCAO procedure were anesthetized and underwent exposure of the common carotid artery without subsequent occlusion of the middle cerebral artery.

\section{Drug treatment}

All animals were treated prophylactically with ketoprofen (10 mg/kg s.c.), atropine $(0.25 \mathrm{mg} / \mathrm{kg}$ s.c.) with two additional doses of ketoprofen at 24 and $48 \mathrm{~h}$ post-MCAO. Recombinant human LIF (ProSpec, Ness Ziona, Israel) $(125 \mu \mathrm{g} / \mathrm{kg})$ or PBS (pH 7.4) was administered intravenously at 6,24 , and $48 \mathrm{~h}$ post-MCAO as previously described [46, 47]. Animals were randomly assigned to treatment groups and all lab personnel administering drugs were blinded to treatments.

\section{Tissue collection}

Rats were euthanized at $72 \mathrm{~h}$ post-MCAO via intraperitoneal injection of ketamine/xylazine solution $(75 \mathrm{mg} / \mathrm{kg}$ and $7.5 \mathrm{mg} / \mathrm{kg}$ ) [53]. Spleens were collected immediately prior to perfusion. Animals used for immunohistochemical analysis were perfused transcardially with normal saline followed by $4 \%$ paraformaldehyde in phosphate buffer. Animals used for biochemical analysis were perfused with saline but not paraformaldehyde prior to obtaining tissue. Fresh brain tissue was separated into ipsilateral and contralateral hemispheres, snap-frozen, and stored at $-80{ }^{\circ} \mathrm{C}$ until further processing. Fixed brains were cryopreserved in $20 \%$ followed by $30 \%$ sucrose solutions and cut into $30-\mu \mathrm{m}$ sections using a cryostat. Brain tissue used in these experiments was located between +1.7 and $-3.3 \mathrm{~mm}$ from the bregma.

\section{Tissue homogenization}

To obtain whole cell extracts, frozen tissue was homogenized in whole cell lysis buffer containing the following: $50 \mathrm{mM}$ Tris pH 8, $150 \mathrm{mM} \mathrm{NaCl}, 0.1 \%$ SDS, $1 \%$ IGEP AL, $1 \mathrm{mM}$ PMSF, and a Complete Mini protease inhibitor cocktail (Roche Diagnostics, Indianapolis, IN). An electric homogenizer was used to disrupt tissue, and lysates were incubated on ice for $20 \mathrm{~min}$. Tissue lysates were vortexed and pipetted to break up nuclei. Protein concentrations were determined by performing a Bradford Assay according to the manufacturer's protocol (Bio-Rad, Hercules, CA). Briefly, Bradford reagent containing Coomassie blue was added to diluted protein samples and absorbance was read at $595 \mathrm{~nm}$ using a SmartSpec 3000 spectrophotometer (Bio-Rad). Concentrations were determined by comparing the absorbance readings against a standard curve.

\section{Isolectin staining}

Isolectin IB4 $(0.05 \% v / v)$ from Griffonia simplicifolia conjugated to AlexaFluor ${ }^{\circ} 488$ dye was used to label activated macrophages and microglia in the cortical and striatal tissue of PBS- and LIF-treated rat brains according to a previously described procedure [20]. Coverslips were mounted onto slides using VECTASHIELD ${ }^{\circ}$ medium containing 4', 6-diamidino-2-phenylindole (DAPI) (Vector 
Labs, Burlingame, CA). Images were captured using a Nikon Eclipse Ti microscope (Minato, Tokyo, Japan) interfaced with NIS Elements Imaging Software (Nikon).

\section{3,3-Diaminobenzidine immunohistochemistry}

To detect CD11b-positive cells in brain tissue, 3,3-diaminobenzidine (DAB) immunohistochemistry was performed according to a previously described protocol [54]. The following antibodies were used: mouse $\alpha$-CD11b (OX42) (1:3000; Bio-Rad; Hercules, CA) and horse $\alpha$-mouse (1:300; Vector-Labs; Berlingame, CA). Slides were cover slipped with DPX medium (BDH Laboratories, Poole, England) and images were acquired with a Nikon Eclipse Ti microscope interfaced with NIS Elements Imaging Software (Nikon).

DAB staining of spleen tissue was also performed according to a previously described protocol, albeit with minor modifications. Briefly, cryopreserved spleen tissue sections $(30 \mu \mathrm{m})$ were dried at $37{ }^{\circ} \mathrm{C}$, rehydrated with PBS (pH 7.4), and permeabilized for $1 \mathrm{~h}$ containing $10 \%$ goat serum, $0.3 \% 1 \mathrm{M}$ Lysine, and $0.3 \%$ Triton-X-100. Following permeabilization, spleen sections were treated for 40 min with $3 \% \mathrm{H}_{2} \mathrm{O}_{2}$ to quench endogenous peroxidase activity. Sections were incubated overnight in the following antibodies: rabbit $\alpha$-LIFR (1:200; Santa Cruz; RRID:AB_2136015) and mouse $\alpha$-FoxP3 (1:5000; Abcam; RRID:AB_447114). Secondary detection was achieved using goat $\alpha$-rabbit and goat $\alpha$-mouse biotinylated secondary antibodies (1:300; Vector Labs). Slides were mounted with DPX medium (BDH Laboratories) after dehydration with ethanol and clearing with xylenes. All images were acquired using a Nikon Eclipse Ti microscope interfaced with NIS Elements Imaging Software (Nikon).

\section{Western blot analysis}

Western blotting was used for semi-quantitative measurement of protein expression using a previously described procedure [47]. Briefly, whole cell lysates from brain and spleen tissue were run on 10\% SDS-PAGE gels and transferred to nitrocellulose membranes. Membranes were blocked in Li-Cor TBS-based Blocking Buffer (Lincoln, $\mathrm{NE}$ ) and probed with the following antibodies: rabbit $\alpha$-LIFR (1:100; Santa Cruz), rabbit $\alpha$-IL-12 p40 (1:100; Abbiotec RRID:AB_10636335), mouse $\alpha$-CD11b (1:1000; Abcam). Membranes were incubated in IRDye $800 \mathrm{CW}$ goat $\alpha$-rabbit antibodies $(1: 20,000$; Li-Cor; RRID:AB_2651127) for detection of protein bands. Membranes were visualized using the Odyssey CLx Imaging System (Li-Cor). To normalize for loading, membranes containing whole cell extracts were re-probed with mouse $\alpha$ - $\beta$-actin (1:5000; Novus Biologicals; RRID:AB_1216153) and IRDye 680RD goat $\alpha$-mouse antibodies (1:20,000; Li-Cor; RRID:AB_10956588).

\section{Bone marrow-derived macrophage cell culture}

Bone marrow-derived macrophages (BMDMs) were isolated from C57BL/6 mice (3 months of age) as previously described [55-57]. Briefly, cells were extracted from the femur and tibia and seeded at a density of $8 \times 10^{5}-1 \times 10^{6}$ cells $/ \mathrm{ml}$ in Dulbecco's modified Eagle's medium (DMEM) containing $10 \% \mathrm{FBS}, 1 \%$ penicillin/streptomycin, $1 \%$ HEPES, $0.001 \% \beta$-mercaptoethanol, and $20 \%$ supernatant containing macrophage colony-stimulating factor from SL929 cells (gifted by Phillip Popovich from The Ohio State University) [58]. Following 7 days of in vitro differentiation, cells were re-seeded at a density of $1 \times 10^{6}$ cells $/ \mathrm{ml}$ in DMEM containing 10\% FBS, $1 \%$ penicillin/ streptomycin, $1 \%$ HEPES, and $0.001 \% \beta$-mercaptoethanol. The next day, a classically activated phenotype (M1) was induced using N2A medium containing LPS $(50 \mathrm{ng} / \mathrm{ml})$ and IFNY $(20 \mathrm{ng} / \mathrm{ml})$. LIF $(20 \mathrm{ng} / \mathrm{ml})$ or PBS was co-administered with the LPS and IFNY. Macrophageconditioned media was collected $24 \mathrm{~h}$ after stimulation and centrifuged at $13,000 \mathrm{rpm}$ at $4{ }^{\circ} \mathrm{C}$ for $10 \mathrm{~min}$ prior to measurement of IL-12 p40 and IL-10 via ELISA [59].

\section{ELISA}

To measure the release of IFN $\gamma$, TNF $\alpha$, IL-1 $\beta$, IL-6, and IL-10 in rat spleen tissue, ELISA was performed according to manufacturer's protocol using the appropriate DuoSet ELISA kits (R\&D Systems, Inc., Minneapolis, MN). ELISA was also used to measure IL-12 p40 and IL-10 release in macrophage supernatants according to the manufacturer's protocol using the Mouse IL-12 p40 and IL-10 ELISA kits (Cat \# EMIL12P40 and Cat \# EM2IL105; Thermo Fisher Scientific, Waltham, MA).

\section{Data analysis}

Images were minimally processed in a uniform matter across treatment groups and were analyzed using ImageJ software (NIH, Bethesda, MD). The D'Agostino-Pearson test was performed to determine whether data was normally distributed. Statistical analysis for experiments containing two groups was performed using Student's $t$ test, or the Mann-Whitney $U$ Test if the data sets did not pass the D'Agostino-Pearson test. Welch's correction was used in the case of unequal variances. Statistical analysis for experiments containing three or more groups was performed using the one-way ANOVA followed by Fisher's Protected LSD test to determine individual differences If data did not pass the D'Agostino-Pearson test, the Kruskal-Wallis $H$ test was used, and individual differences were detected using Bonferroni-corrected MannWhitney $U$ tests. A $p$ value equal to 0.05 or less was considered statistically significant. All reported $p$ values are one-tailed. 


\section{Results}

LIF decreases LIFR expression but does not alter spleen weight after MCAO

Western blotting was used to determine whether MCAO and LIF treatment altered levels of LIFR in the spleen at $72 \mathrm{~h}$ post-MCAO. At $72 \mathrm{~h}$ post-MCAO, there was a significant change in splenic LIFR expression among sham, PBS, and LIF-treated rats $\left(F_{2,21}=3.511 ; p=0.0484\right)$. LIFR levels in the spleens of LIF-treated $(p=0.0086)$ but not PBS-treated rats were significantly lower than those of sham rats (Fig. 1a). When the levels of LIFR were normalized to the weight of each spleen, there was no significant difference in normalized splenic LIFR levels between sham-operated, PBS-treated, and LIF-treated rats $(H=4.295 ; p=0.1168)$. However, there was a trend towards increased normalized LIFR levels in PBS-treated rats compared to the other treatment groups (Fig. 1b). Compared to spleens from sham-operated rats, MCAO and LIF treatment caused a significant overall change in the average spleen weight $\left(p=0.0008, F_{2,56}=8.143\right)$. There was a significant decrease in spleen weight among rats treated with $\mathrm{PBS}$ after MCAO compared to the sham-operated rats $(p=0.0001)$. Rats treated with LIF after MCAO had significantly smaller spleen weights compared to sham-operated rats $(p=0.0062)$. There was a trend towards larger spleens among rats treated with LIF post-MCAO compared to the PBS-treated group, but this trend was not significant ( $p=0.1016$; Fig. 1c).

\section{Splenocytes express the LIF receptor after MCAO and LIF treatment}

Spleen tissue sections were stained with antibodies against LIFR in order to visualize the LIF receptor in splenocytes after sham surgery, MCAO + PBS treatment, and MCAO + LIF treatment. Punctate LIFR immunoreactivity was observed in spleens from sham-operated rats while spleens from the MCAO + PBS and MCAO + LIF groups showed more diffuse staining in splenocytes. Arrows are used to identify representative cells (Fig. 2).

\section{Splenic CD11b expression decreases after MCAO and LIF treatment}

Western blotting was used to measure CD11b protein expression in the spleens of PBS and LIF-treated rats euthanized at $72 \mathrm{~h}$ after MCAO. At $72 \mathrm{~h}$, levels of $\mathrm{CD} 11 \mathrm{~b}$ in spleen tissue were significantly altered after MCAO and LIF treatment $\left(p=0.0003 ; F_{2,21}=12.51\right)$. There was a significant drop in CD11b levels in the spleens of PBS-treated rats $(p=0.002)$ and LIF-treated $(p=0.0002)$ rats compared to those of sham rats (Fig. 3a). When the CD11b levels were normalized to the spleen weights of each sample, there was a significant overall change in normalized CD11b levels $(p=0.0335$; $\left.F_{2,21}=4.009\right)$ and a significant decrease in normalized

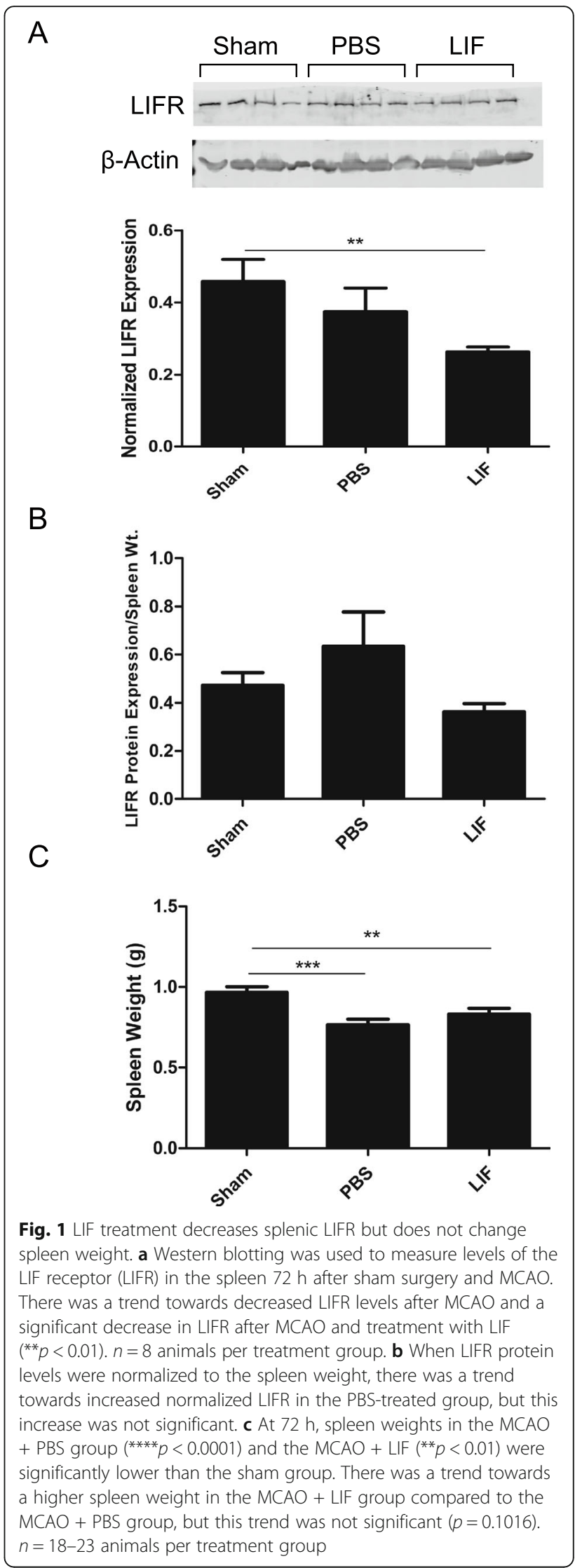




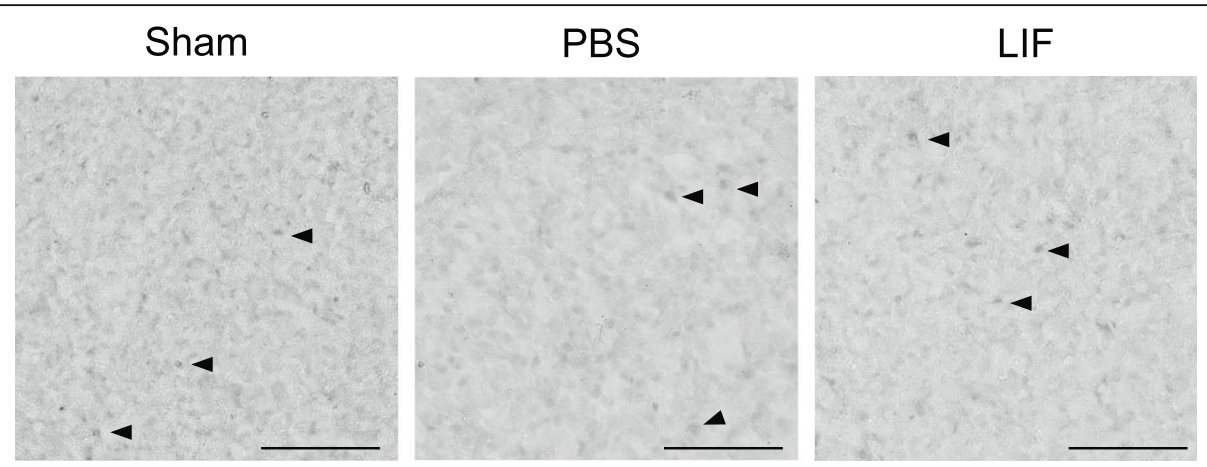

Fig. 2 LIFR+ splenocytes are observed in the spleen after MCAO and LIF treatment. DAB immunohistochemistry was used to visualize the expression of LIFR among splenocytes in tissue from sham-operated, PBS-treated, and LIF-treated cells. Although LIFR+ splenocytes were found in all three treatment groups, LIFR+ positive cells showed punctate immunoreactivity while tissue from PBS- and LIF-treated animals showed more diffuse immunoreactivity. Arrows identify representative cells. Scale bar $=50 \mu \mathrm{m}$

CD11b after MCAO + LIF treatment compared to sham levels $(p=0.0043$; Fig. $3 \mathrm{~b}$ ). To determine the relationship between spleen weight and levels of CD11b in splenic tissue, Pearson $r$ correlation analysis was performed. There was a significant positive correlation between the spleen weight at $72 \mathrm{~h}$ post-MCAO and sham procedure and splenic CD11b protein expression $(p=0.0149$; Pearson $r=0.4437$; Fig. 3c).

\section{IL-12 p40 levels in the spleen are not altered after MCAO and LIF treatment}

To measure release of IL-12 after MCAO and LIF treatment, western blotting was used to detect levels of IL-12 p40 in splenic tissue. There was no overall significant alteration in IL-12 p40 protein levels at $72 \mathrm{~h}$ after MCAO and LIF treatment $\left(p=0.098 ; F_{2,21}=2.600\right)$. However, there was a strong trend towards decreased IL-12 p40 levels in the spleens of LIF-treated rats compared to PBS-treated and sham rats (Fig. 4a). When splenic IL-12 p40 levels were normalized to spleen weights, there was a trend towards increased normalized IL-12 p40 levels in the spleens of PBS-treated rats compared to LIF-treated and sham-operated rats $\left(F_{2,21}=2.721, p=0.0890\right.$; Fig. $\left.4 \mathrm{~b}\right)$.

\section{TNFa, but not IL-6 and IL-1b, are altered by MCAO + LIF} treatment at $72 \mathrm{~h}$ after MCAO

ELISA was used to measure levels of TNF $\alpha$ in the spleen tissue of sham, PBS-treated, and LIF-treated rats at $72 \mathrm{~h}$ after MCAO. There was a significant alteration in TNF $\alpha$ levels at this time point $\left(F_{2,21}=6.181 ; p=0.0077\right.$. TNF $\alpha$ levels were significantly lower after MCAO compared to sham levels $(p=0.0347)$ and after MCAO + LIF treatment compared to sham levels $(p=0.0012)$. However, there was no significant difference between the mean TNF $\alpha$ levels in the MCAO + PBS and MCAO + LIF groups $(p=0.1038$; Fig. 5a). ELISA was also used to measure levels IL-1 $\beta$ and IL-6 in spleen tissue. There was a trend towards decreased IL-1 $\beta\left(F_{2,20}=3.157 ; p=0.0644 ;\right.$ Fig. $\left.5 \mathrm{~b}\right)$ and
IL-6 $\left(F_{2,13}=0.3225 ; p=0.7300 ;\right.$ Fig. $\left.5 c\right)$ levels after MCAO + LIF treatment but this difference was not statistically significant.

\section{Splenic IL-10 is not altered by MCAO + LIF treatment}

Levels of IL-10 were measured in spleen tissue at $72 \mathrm{~h}$ post-MCAO using ELISA. Although there was a trend towards decreased IL-10 levels in the MCAO + PBS and $\mathrm{MCAO}+$ LIF groups that approached significance $\left(F_{2,20}=3.437 ; p=0.0521\right)$, the overall difference was not statistically significant (Fig. 6).

\section{LIF reduces CD3 immunoreactivity in the spleen}

To determine whether LIF decreases development of mature T cells, western blotting was used to measure levels of CD3, a pan-T cell marker, in spleen tissue at $72 \mathrm{~h}$ after MCAO. At $72 \mathrm{~h}$, there was a significant change in CD3 levels between spleen tissue from sham-operated, PBS-treated, and LIF-treated young rats $\left(F_{2,20}=5.198, p=0.0152\right)$. There were significant decreases in overall CD3 levels in the spleens of PBS-treated ( $p=0.0405)$ and LIF-treated rats compared to sham-operated rats $(p=0.0113$; Fig. 7a). When CD3 levels were normalized to spleen weight, there was no significant difference in normalized CD3 between the three treatment groups $\left(F_{2,20}=2.434 ; p=0.1132\right.$; Fig. $\left.7 \mathrm{~b}\right)$.

\section{FoxP3+ immunoreactivity is observed in the spleen after MCAO + LIF treatment}

Spleen sections from sham-operated, PBS-treated, and LIF-treated rats were stained with FoxP3 antibodies to identify the presence of Tregs. FoxP3+ cells were found in representative spleen sections from all three treatment groups, although FoxP3 immunoreactivity was more prominent in the representative sections from the $\mathrm{MCAO}+$ PBS and MCAO + LIF groups (Fig. 8). 


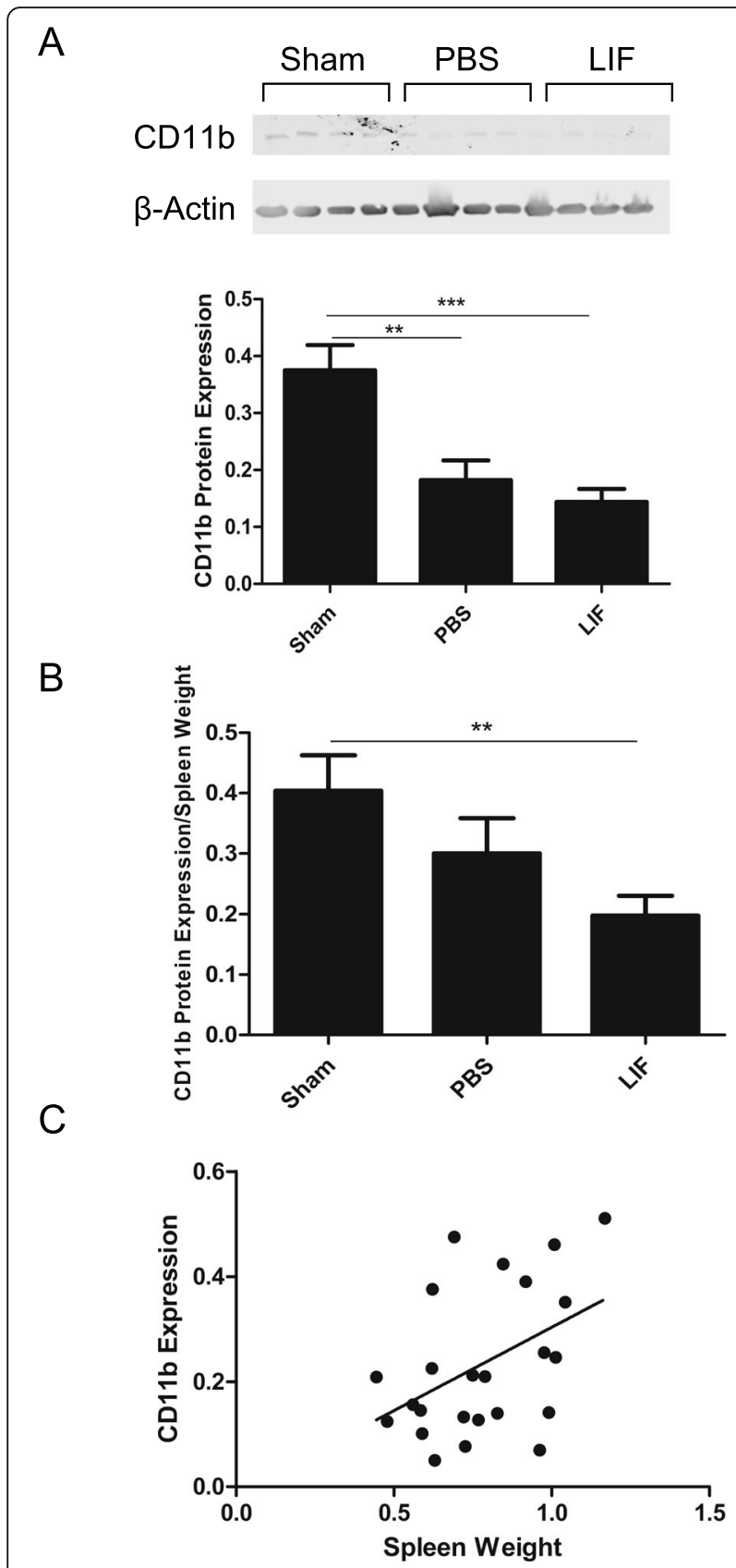

Fig. 3 Splenic CD11b levels are significantly decreased after MCAO and LIF treatment. a Western blotting was used to measure levels of CD11b, a marker of activated macrophages/microglia, in the spleen $72 \mathrm{~h}$ after sham surgery and MCAO. Levels of CD11B were significantly lower in the MCAO + PBS group $\left({ }^{* *} p<0.01\right)$ and the $M C A O+\operatorname{LIF}\left({ }^{* *} p<0.001\right)$ were significantly lower than the sham group. $\mathbf{b}$ When CD11b levels were normalized to spleen weight, there was a significant decrease in normalized CD11b after LIF treatment compared to sham levels $(* * p<0.01)$. c According to the results of the Pearson correlation analysis, there was a significant correlation between spleen weights and CD11b levels in the spleen $\left({ }^{*} p<0.05\right) \cdot n=8$ animals per treatment group

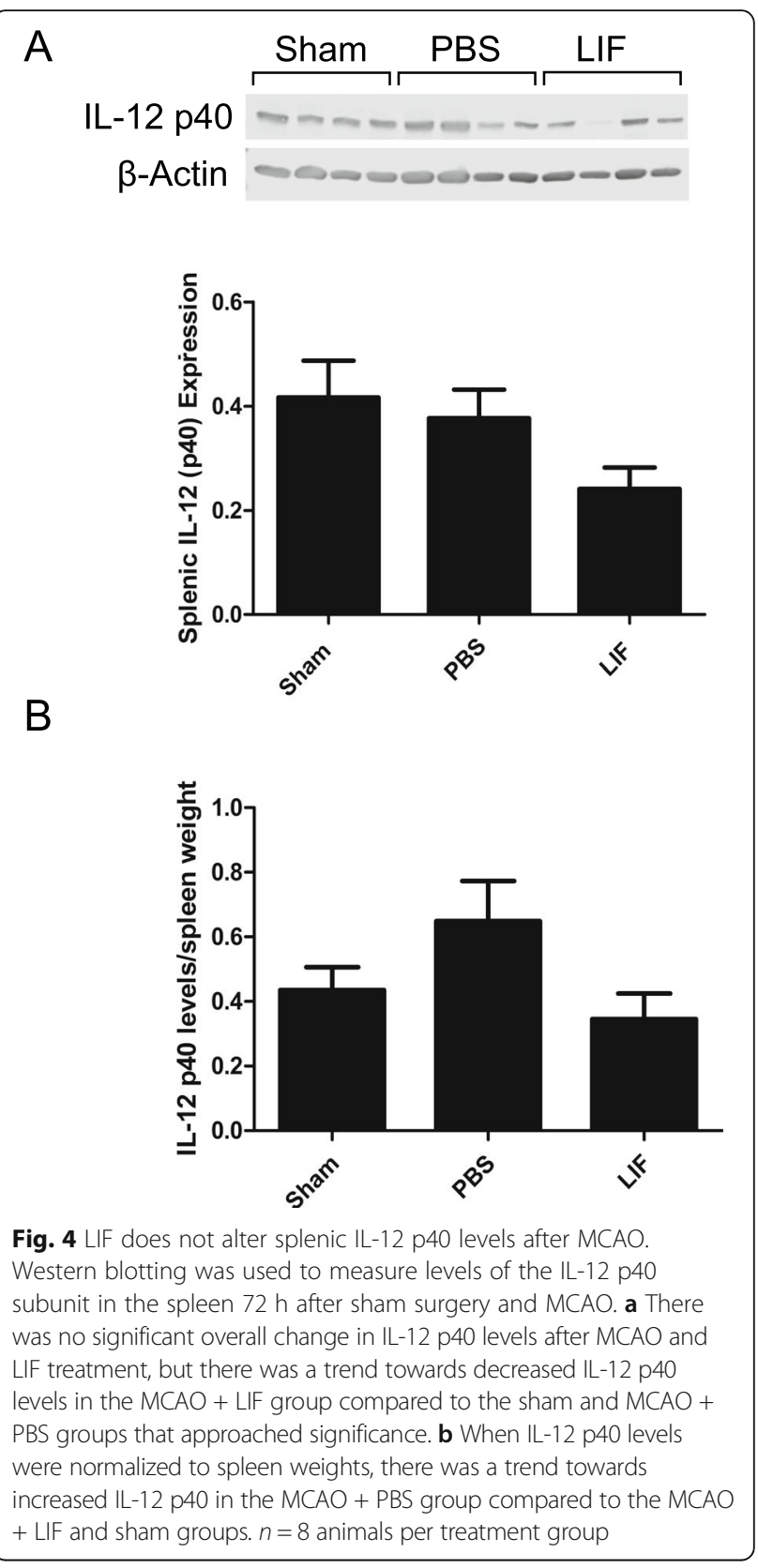

IFN $\gamma$ release is decreased by MCAO and LIF treatment

IFN $\gamma$ levels in spleen tissue from sham, PBS-treated, and LIF-treated rats was measured using an ELISA kit and normalized to the total protein. There was a significant change in IFNy levels in the spleen tissue of sham-operated, PBS-treated, and LIF-treated rats at $72 \mathrm{~h}$ post-MCAO $\left(F_{2,21} 6.365 ; p=0.0069\right)$. There was a significant decrease in IFN $\gamma$ levels in the spleens of the $\mathrm{MCAO}+$ PBS group $(p=0.0364)$ and the MCAO + LIF group $(p=0.0095)$ compared to the sham levels. In addition, spleen tissue from the MCAO + LIF group had significantly lower IFN $\gamma$ levels compared to tissue from 


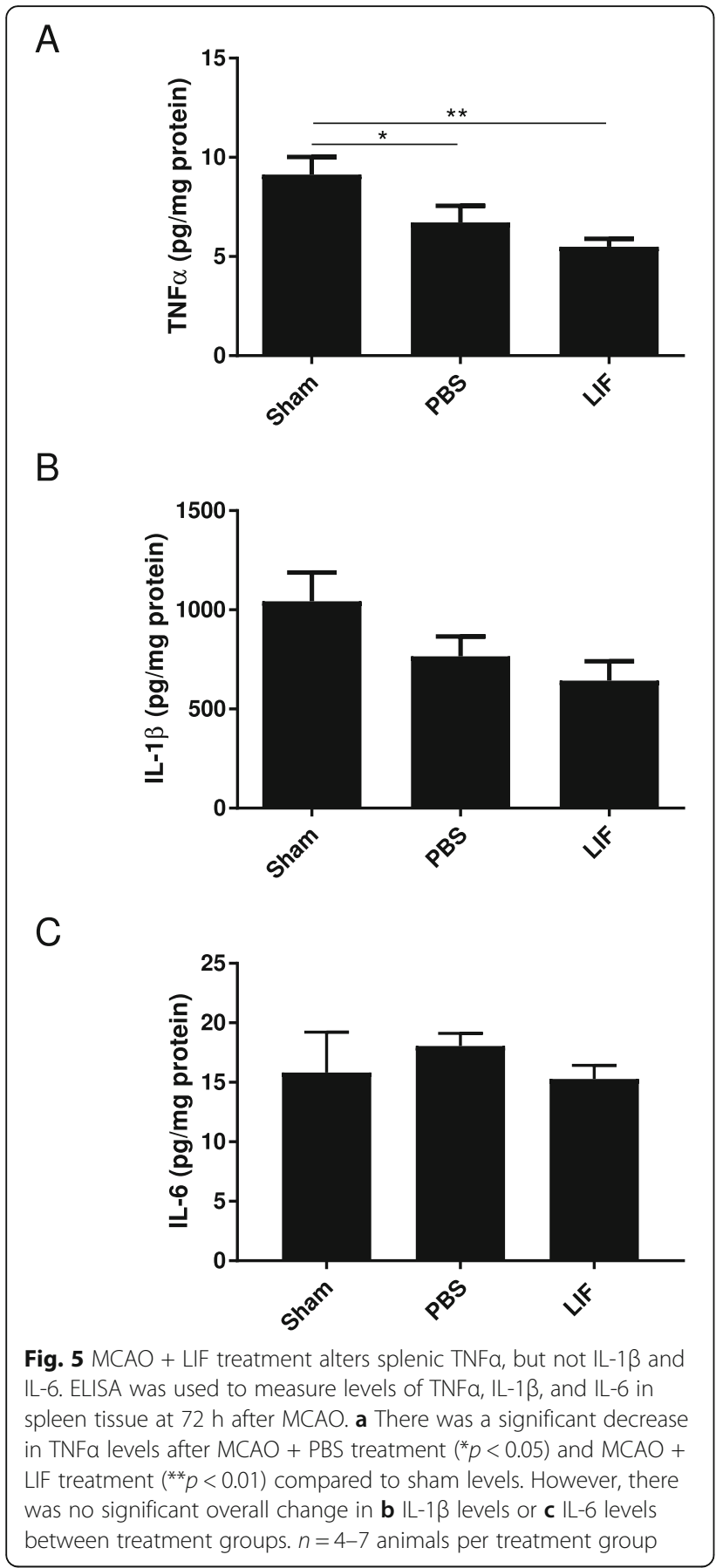

the MCAO + PBS rats ( $p=0.0324$; Fig. 9a). Normalizing IFN $\gamma$ levels in each sample to the spleen weight also showed a significant alteration in normalized splenic IFN $\gamma$ after MCAO and LIF treatment $\left(F_{2,21}=\right.$ 5.052, $p=0.0162)$. MCAO + PBS treatment significantly increased normalized IFN $\gamma$ compared to sham levels $(p=0.0038)$, but LIF treatment significantly reduced normalized IFN $\gamma$ levels compared to PBS treatment ( $p=0.0080$; Fig. 9b).

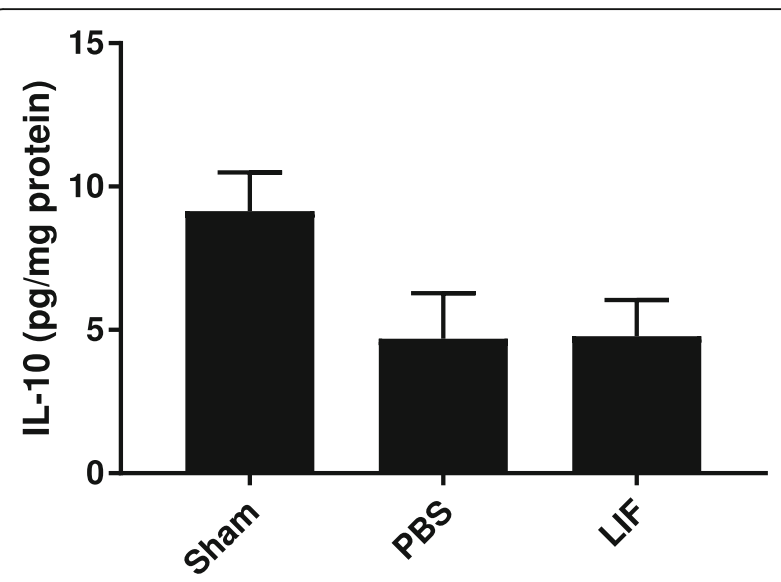

Fig. 6 IL-10 levels are not altered by MCAO and LIF treatment. ELISA was used to measure IL-10 in spleen tissue samples. Although there was a trend towards decreased IL-10 after MCAO (regardless of PBS or LIF treatment), the change was not quite statistically significant overall. $n=7-8$ animals per treatment group

\section{LIF treatment counteracts the increase in splenic IP-10} after MCAO

IP-10 levels were measured in splenic tissue using western blotting. At $72 \mathrm{~h}$ after MCAO, there was a significant alteration in IP-10 protein expression in spleen tissue $(H=7.215$; $p=0.0271)$. Splenic IP-10 levels were significantly elevated after MCAO compared to sham levels $(p=0.0045)$. The levels of IP-10 in the spleens of LIF-treated rats were not significantly different from sham levels $(p=1.000)$, but there was a non-significant decrease in IP-10 expression compared to IP-10 expression levels of PBS-treated rats ( $p=0.1572$; Fig. 10a). When the levels of IP-10 in each tissue sample were normalized to the spleen mass, there was a significant change in normalized IP-10 levels at $72 \mathrm{~h}$ post-MCAO $(H=9.065 ; p=0.0108)$. Normalized IP-10 levels remained significantly elevated compared to the sham group $(p=0.0015)$. However, treatment with LIF counteracted this upregulation of IP-10 compared to sham-operated animals (Fig. 10b).

\section{LIF promotes anti-inflammatory phenotype in LPS/IFN $\gamma^{-}$ stimulated macrophages}

Prior to stimulation with LPS + IFN $\gamma$ to induce an M1 phenotype, BMDMs were treated with LIF $(20 \mathrm{ng} / \mathrm{ml})$ or PBS. Levels of IL-12 p40 and IL-10 in the supernatant were measured via ELISA. Unstimulated cells treated with LIF or PBS were used as a control. After $24 \mathrm{~h}, \mathrm{M} 1$ macrophages stimulated with LIF had released significantly less IL-12 p40 compared to M1 cells treated with $\mathrm{PBS}(t=6.530, \mathrm{df}=4, p=0.0014$; Fig. 11a). M1 BMDMs showed significantly elevated release of IL-10 compared to their unstimulated counterparts. Treatment with LIF prior to stimulation further elevated IL-10 release among M1 cells $(t=2.942, \mathrm{df}=4, p=0.0212$; Fig. $11 \mathrm{~b})$. LIF treatment 


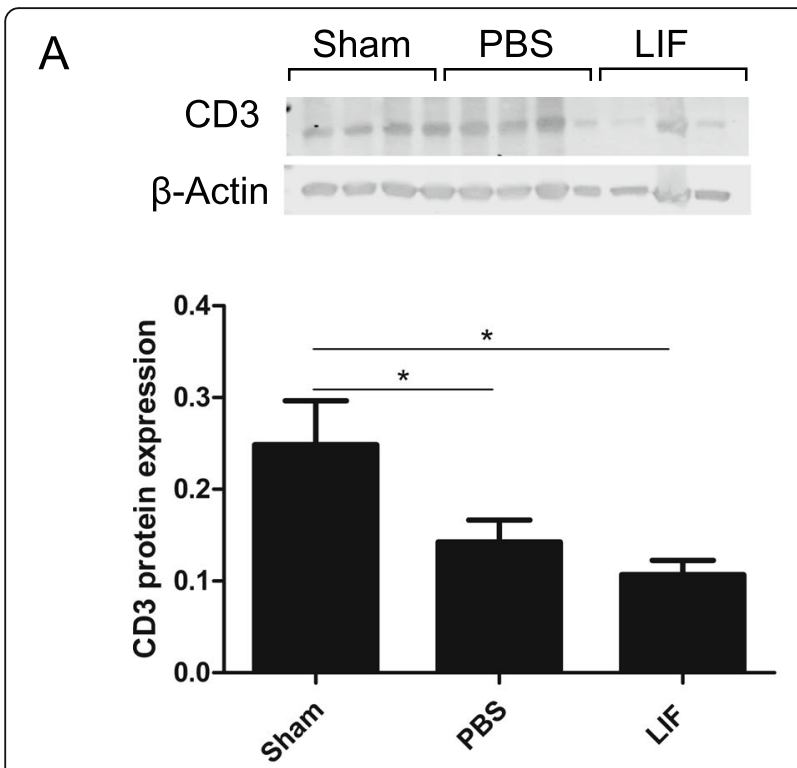

B

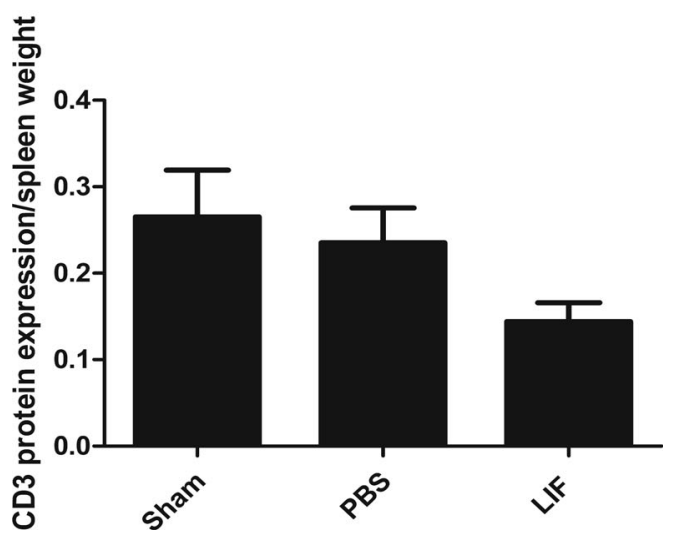

Fig. 7 LIF decreases CD3 levels in the spleen after MCAO. Western blotting was used to measure levels of CD3, a pan-T cell marker, in spleen tissue. a At $72 \mathrm{~h}$ after sham surgery or MCAO, there was a significant decrease in CD3 levels between sham-operated rats and the PBS and LIF treatment groups $\left({ }^{*} p<0.05\right)$. $\mathbf{b}$ However, there was no significant change in CD3 expression when protein levels were normalized to spleen weights. $n=7-8$ animals per treatment group

also significantly decreased the ratio of IL-12 p40 release to IL-10 release in the media compared to treatment with PBS $(t=6.012, \mathrm{df}=4, p=0.0019$; Fig. 11c).

\section{Activated macrophages/microglia are decreased in the brains of LIF-treated rats}

Activated macrophages/microglia were visualized in fixed brain tissue from PBS- or LIF-treated rats using isolectin-conjugated to AlexaFluor 488 dye. At $72 \mathrm{~h}$ after MCAO, there was a less isolectin-tagged fluorescence within the cortical and striatal tissue of LIF-treated rats compared to their PBS-treated counterparts. Furthermore, representative images show that lectin-binding cells in the striatum after LIF treatment displayed a more ramified phenotype. By contrast, lectin-binding cells in the striatum displayed an amoeboid phenotype after PBS treatment (Fig. 12a).

Antibodies against CD11b were also used to label brain sections from animals treated with PBS or LIF after MCAO. Representative images show a number of amoeboid CD11b + cells in the cortex and striatum of tissue from animals treated with PBS after MCAO. By contrast, the cortical and striatal tissue from LIF-treated rats contained more $\mathrm{CD} 11 \mathrm{~b}+$ cells with a ramified phenotype (Fig. 12b).

Western blotting was used to quantify protein levels of CD11b in homogenized brain tissue at $72 \mathrm{~h}$ after MCAO. Levels of CD11b in the ipsilateral tissue of PBSand LIF-treated rats were normalized to the average CD11b levels in sham brains. There was a significant change in CD11b levels in the brain after MCAO and LIF treatment $\left(F_{3,18}=7.800 ; p=0.0015\right)$. CD11b levels were significantly decreased in the ipsilateral hemisphere of LIF-treated rats compared to those of PBS-treated rats at $72 \mathrm{~h}$ after MCAO $(p=0.0432)$. Likewise, CD11b levels were significantly higher in the ipsilateral hemisphere of LIF-treated rats $(p=0.0301)$ and PBS-treated rats $(p=0.0037)$ compared to their contralateral counterparts (Fig. 12c).

\section{Discussion}

Although LIF treatment decreased protein levels of CD11b as well as the numbers of isolectin-binding cells, these results indicate that LIF exerts its primary immunomodulatory effects on splenocytes, specifically through the IL-12 p40/IFN $/$ IP-10 axis. Offner et al. previously demonstrated that induction of focal cerebral ischemia in mice stimulates the production of several pro-inflammatory cytokines from splenocytes [60]. This upregulation of cytokine production is followed by a time-dependent decrease in spleen weight due to the migration of splenocyte populations to the ischemic brain [18, 23, 26, 27].

In accordance with previously published studies, spleen size significantly decreased after MCAO compared to sham treatment, LIF-treated rats had a trend towards a larger spleen size at $72 \mathrm{~h}$ after MCAO. Furthermore, there was a significant downregulation in splenic LIFR protein expression in the spleens of LIF-treated rats. LIFR is degraded after prolonged stimulation with LIF in many cell types, which indicates that the splenocytes were responsive to peripherally administered LIF after stroke [61]. Although this laboratory has previously shown that the decrease in spleen size is observed as early as $24 \mathrm{~h}$ after stroke, this laboratory did not observe any LIF-mediated alteration in LIFR expression or spleen size prior to the 72-h time point [27]. 


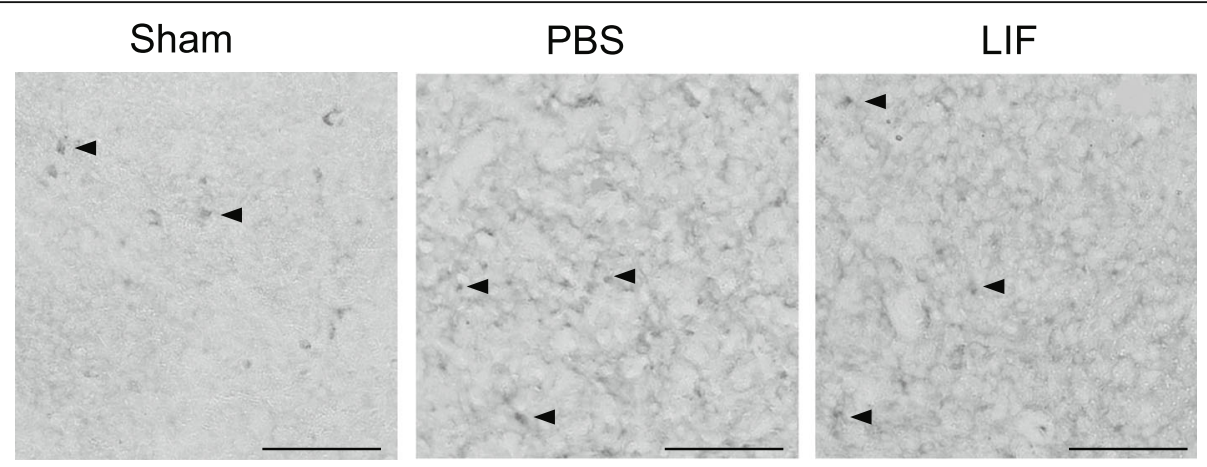

Fig. 8 FoxP3+ cells are observed in the spleen after MCAO and LIF treatment. Antibodies against FoxP3 were used to label Tregs in representative spleen tissue sections. Although FoxP3+ cells were found in representative tissue of sham-operated animals, there was noticeably more immunoreactivity for FoxP3 in spleens of MCAO + PBS and MCAO + LIF animals. Arrows identify representative cells. Scale bar $=50 \mu \mathrm{m}$

However, published manuscripts from this group have also shown that most prominent effects of LIF are observed at $72 \mathrm{~h}$ after MCAO, including improvement in motor skills, decreased tissue damage, and upregulation of antioxidant enzymes [46, 47]. Therefore, it should be expected that the prominent anti-inflammatory effects of LIF are observed at this time point.

Although this study primarily examined the effects of LIF in the spleen and brain after stroke, it is entirely possible that LIF signaling is indirectly modulating the post-stroke immune response through its actions in other tissues. Ajmo et al. previously demonstrated that the activation of adrenoreceptors in the spleen is responsible for the splenic contraction that promotes the migration of immune cells to the brain after stroke [23]. Due to its effects on the hypothalamus-pituitary-adrenal axis [62], it is possible that LIF administration is influencing the post-stroke immune response through the regulation of cortisol release [62, 63]. Furthermore, leukocytes within the peripheral circulation, including $\mathrm{T}$ cells, are responsible for perpetuating inflammation in rodent models of ischemic stroke [60]. Therefore, it is highly likely that systemically administered LIF is also acting on immune cells within the peripheral blood in addition to the spleen.

IL-12 is a heterodimer consisting of two subunits: the $35-\mathrm{kDa}$ p35 subunit and the $40-\mathrm{kDa}$ p40 submit, which is a component of the pro-inflammatory cytokine IL-23. Microglia and perivascular macrophages in brain produce IL-12/IL-23 in response to stimulation with other pro-inflammatory cytokines or damage-associated molecular patterns [19]. IL-12 p40 release from macrophages/microglia promotes further production of IL-12/ IL-23 by microglia/ macrophages and perivascular dendritic cells. After the breakdown of the blood-brain barrier due to matrix metalloproteinase and cytokine production by microglia, IL-12 p40-stimulated CD8+ cytotoxic T cells, CD4+ type 1 helper T (Th1) cells, and NK cells release
IFN $\gamma$ [64-66]. The results of the in vitro experiments with BMDMs demonstrate that LIF directly reduces IL-12 p40 release from pro-inflammatory macrophages. Furthermore, LIF treatment promotes in vitro release of IL-10 in BMDMs, an anti-inflammatory cytokine that counteracts IL-12 p40-mediated production of IFN $\gamma$ [67].

While this upregulation of IL-10 was not observed in spleen tissue, it is possible that the migration of monocytes/macrophages into the peripheral circulation prior to $72 \mathrm{~h}$ after MCAO prevents us from detecting any significant change in IL-12 p40 or IL-10 in the spleen at this time point [20]. LIF treatment also did not significantly alter levels of IL- $1 \beta$ or IL- 6 , which are released primarily by monocytes/macrophages $[68,69]$, at this time point. However, IFN $\gamma$ was significantly reduced in the spleen after LIF treatment, which demonstrates that LIF is primarily influencing the pro-inflammatory signaling generated by splenic $T$ cells $[27,30,53]$.

Our lab has demonstrated an essential role for $\mathrm{T}$ and $\mathrm{NK}$ cell-derived IFN $\gamma$ in the initiation of the post-stroke splenic response. According to Seifert et al., splenic T cells upregulate IFNY at $24 \mathrm{~h}$ post-MCAO. Increased IFN $\gamma$ immunoreactivity in the ipsilateral hemisphere at $72 \mathrm{~h}$ post-MCAO corresponds with the infiltration of splenic leukocytes. A splenectomy performed 2 weeks prior to stroke onset or the administration of antibodies to neutralize IFNy significantly reduced neurodegeneration at $96 \mathrm{~h}$ post-MCAO. However, administration of exogenous IFN $\gamma$ restored the neuroinflammatory response in animals that underwent splenectomy [30, 53]. Following release by $\mathrm{NK}$ cells and $\mathrm{T}$ cells, IFN $\gamma$ induces the production of several chemokines in macrophages/ microglia, including monocyte induced by IFN $\gamma$, interferon-inducible T cell $\alpha$-chemoattractant, and IP-10 [70]. Western blot analysis showed that LIF treatment significantly reduces levels of $\mathrm{CD} 3$, a marker for $\mathrm{T}$ cells, in the spleen at $72 \mathrm{~h}$ post-MCAO. Although CD3 is expressed by all $\mathrm{T}$ cells, this reduction coupled with the 


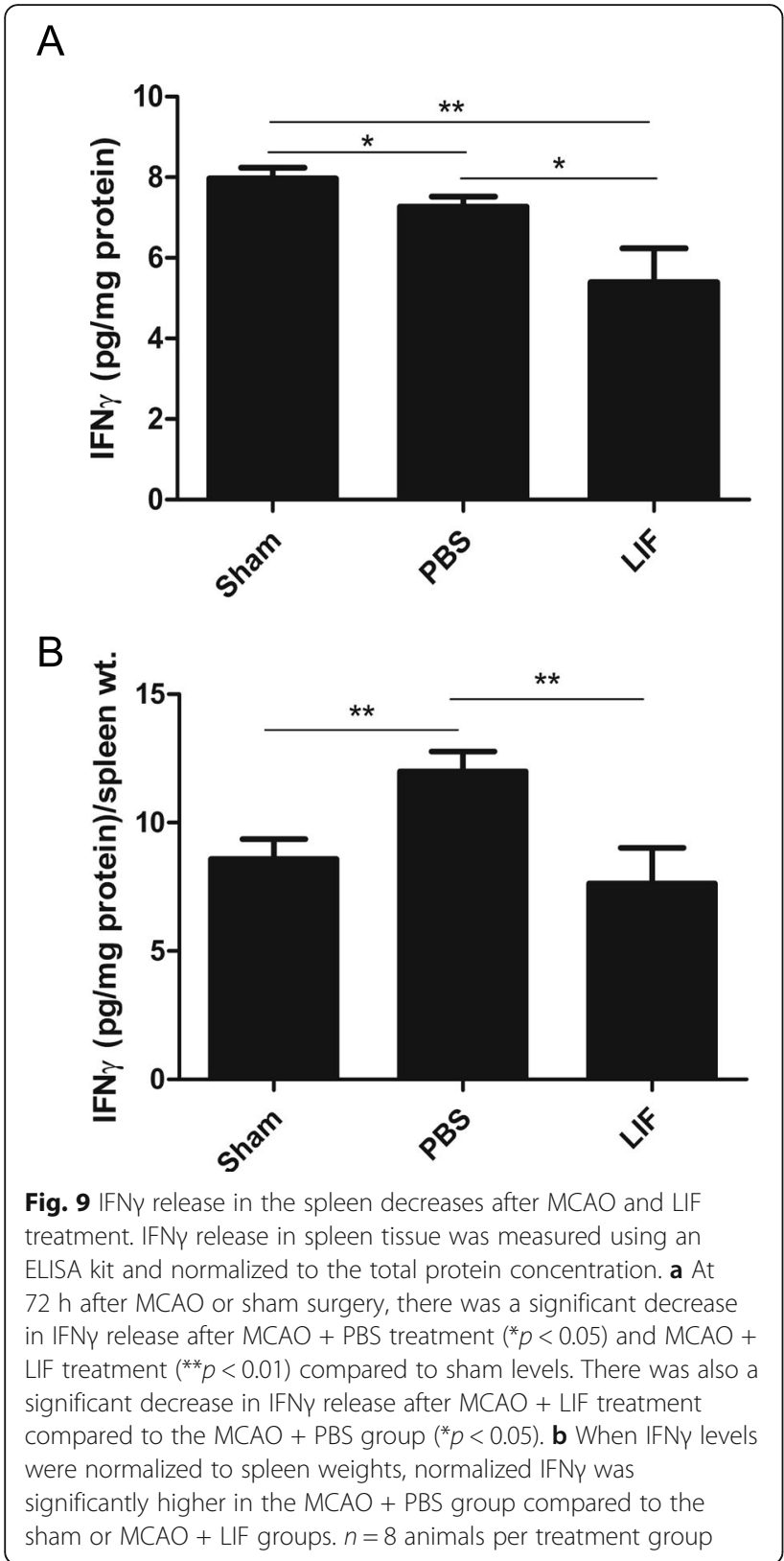

downregulation in IFN $\gamma$ production suggest that LIF prevents the maturation of CD8+ cytotoxic T cells, which are the major producer of IFNY after stroke [71, 72]. FoxP3-labeled spleen tissue from PBS-treated rats did not show a notable difference in immunoreactivity between PBS- and LIF-treated animals. While these results do not rule out a possible effect on CD4 + CD25 + FoxP3+ Tregs, the anti-inflammatory properties of LIF are more likely due to its abilities to suppress IFN $\gamma$ production by $\mathrm{CD} 8+$ and CD4+ Th1 cells.

IP-10 is a chemokine that facilitates chemotaxis of pro-inflammatory $\mathrm{CD} 4+\mathrm{T}$ cells to the ischemic brain via binding to CXCR3 [73]. Alternatively, IP-10, along with

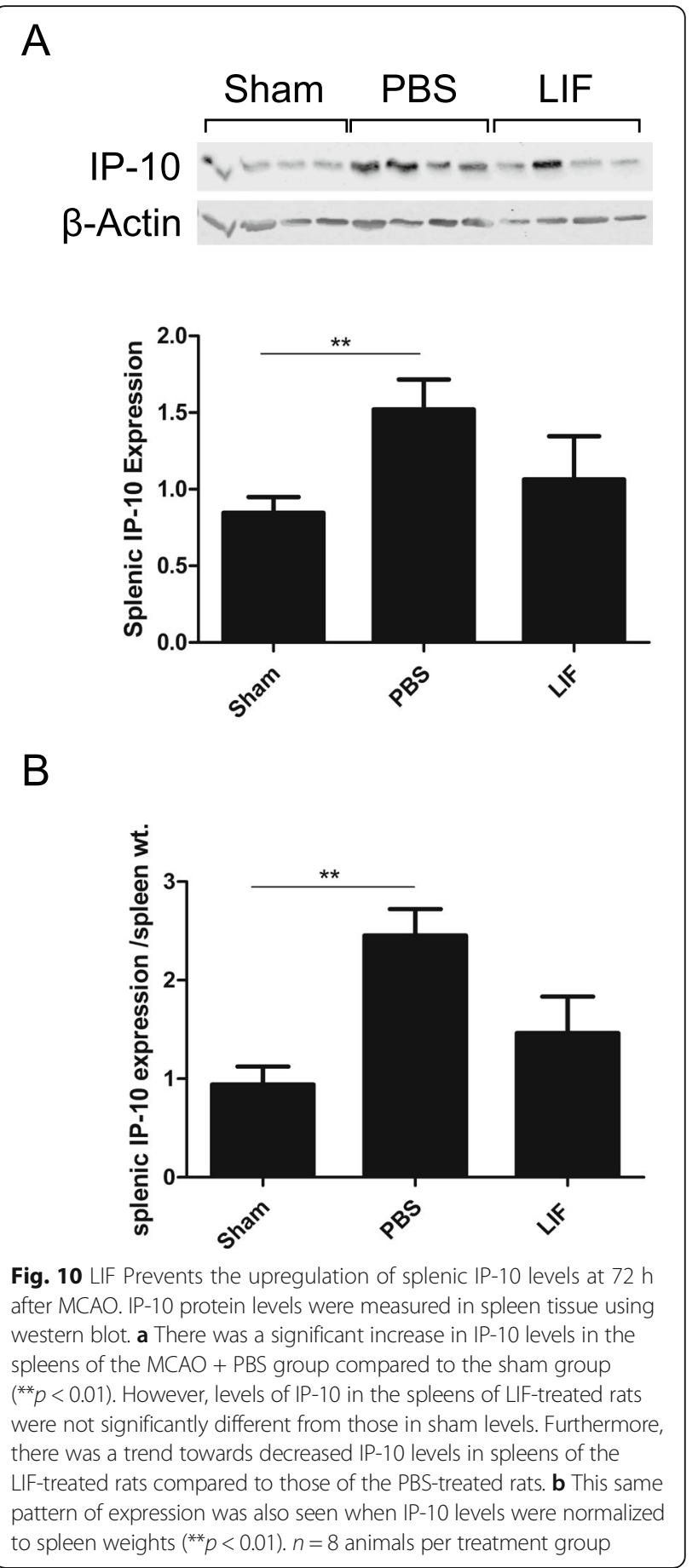

other IFN $\gamma$-inducible chemokines, promotes post-stroke inflammation via antagonism of the binds to the CCR3 receptor on anti-inflammatory CD4+ T cells [74]. Offner et al. first reported that IP-10 mRNA levels were increased at $22 \mathrm{~h}$ after transient MCAO in mice, and Seifert et al. confirmed that the IFNy/IP-10 axis drives the migration of $\mathrm{T}$ cells to the brain after stroke [18, 30, 75]. In this study, splenic IP-10 levels increased after MCAO 


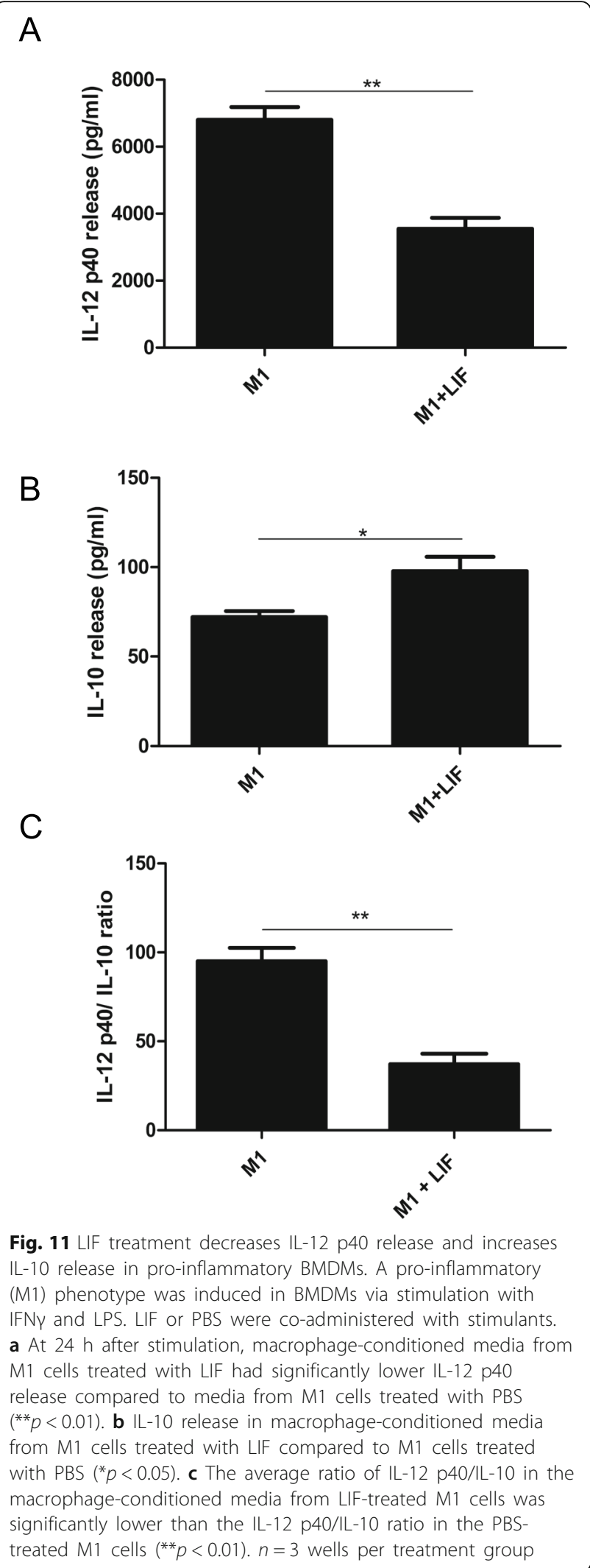

in PBS-treated rats compared to sham-operated rats, but LIF treatment prevented the upregulation of IP-10 after MCAO. By counteracting the IFN $\gamma$-mediated increase in splenic IP-10, LIF treatment would decrease the number of pro-inflammatory immune cells migrating to the brain after stroke (Fig. 13).

Although most of the anti-inflammatory signaling promoted by LIF is occurring in the spleen, the decreased isolectin-tagged fluorescence and normalized CD11b levels in brain tissue demonstrate that LIF either decreases infiltration of monocytes/macrophages into the ischemic hemisphere or attenuates the activation of microglial cells after stroke [76]. According to Leonardo et al., the increase lectin-tagged fluorescence after permanent MCAO corresponds with increased numbers of $\mathrm{CD} 11 \mathrm{~b}+$ monocytes/macrophages into the penumbra [20]. However, we also observed that CD11b + cells in the cortical and striatal tissue of LIF-treated rats had more of a ramified phenotype, while the amoeboid phenotype was more prevalent in the tissue from PBS-treated rats. Therefore, it is possible that LIF treatment influences microglial activation in addition to monocytes/macrophages derived from the spleen. Since IP-10 is primarily responsible for facilitating chemotaxis of immune cells towards the ischemic brain, the decrease in the number of isolectin-tagged cells and CD11b levels could correspond to a smaller population of immune cells leaving the spleen [30, 77]. This explanation is further justified by the trend towards an increase in spleen weight observed after LIF treatment.

Previously released publications from our laboratory and other independent groups demonstrated that LIF promotes tissue repair and functional recovery after MCAO through Akt-dependent upregulation of protective antioxidant enzymes in neurons and oligodendrocytes. However, evidence suggests that certain Akt-inducing biological therapeutics prevent the infiltration of monocytes/macrophages and lymphocytes into the ischemic brain in addition to promoting anti-oxidation. Rowe et al. showed that administration of human umbilical cord blood (HUCB) cells at $48 \mathrm{~h}$ after MCAO promotes oligodendrocyte survival via the upregulation of peroxiredoxin IV and metallothionein III. In a later study by Shahaduzzaman et al., HUCB treatment after MCAO increased peroxiredoxin $\mathrm{V}$ expression in neurons through increased Akt signaling [78]. However, soluble factors released from HUCB cells, which include LIF, also promote anti-inflammatory signaling after stroke [46, 79]. Vendrame et al. demonstrated that intravenously injected HUCB cells migrated to the spleen during $\mathrm{MCAO}$ and partially counteracted the splenic immune response after stroke. Splenocytes isolated from rats treated with human umbilical cord blood cells after MCAO showed significantly decreased 
A
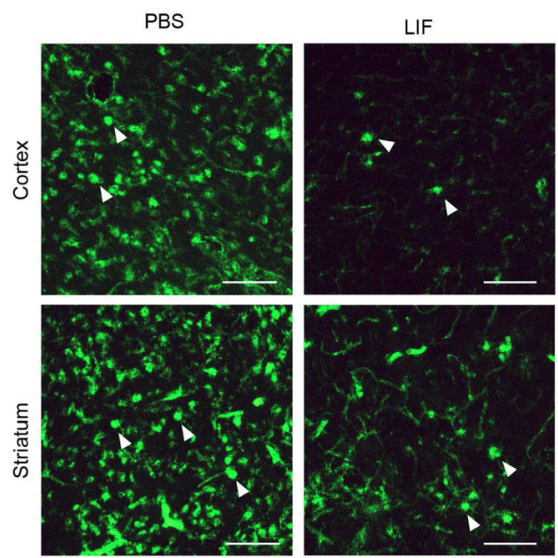

C

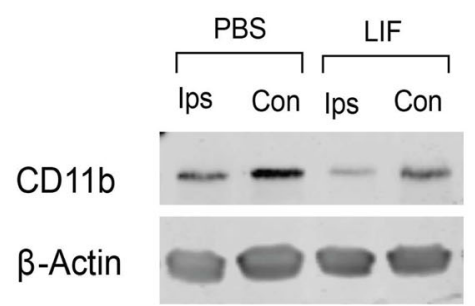

B
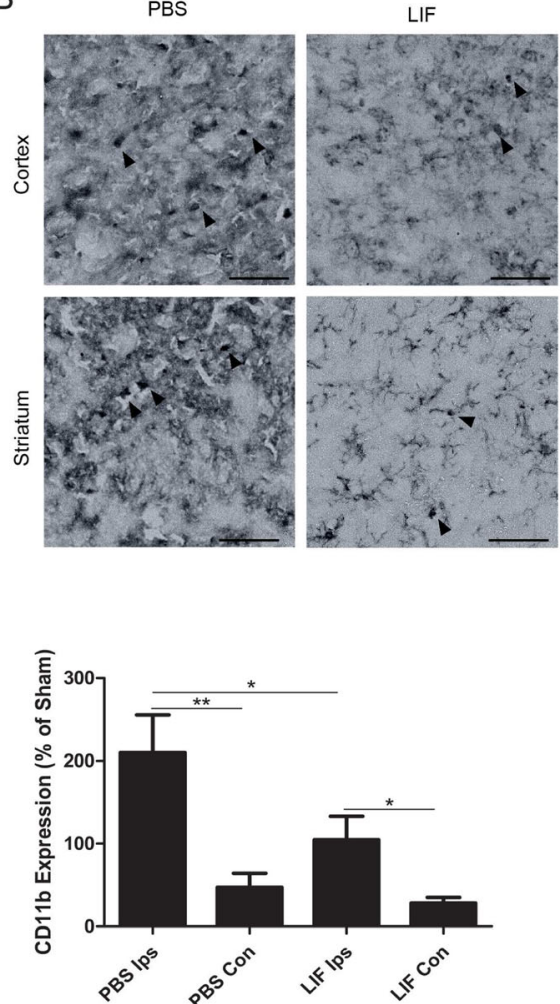

Fig. 12 LIF reduces isolectin-tagged fluorescence and CD11b levels in ischemic brain tissue. a Ipsilateral tissue sections from the MCAO + LIF treatment group showed less isolectin-tagged fluorescence in the cortex and striatum than tissue from the MCAO + PBS treatment group. Furthermore, isolectin-tagged cells in the striatum displayed a ramified phenotype, while isolectin-tagged cells in the striatum showed an amoeboid phenotype after MCAO + PBS treatment. Arrows indicate representative cells. Scale bar $=100 \mu \mathrm{m}$. b CD11b antibodies were also used to label cells in the cortical and striatal brain tissue from representative animals. While more amoeboid CD11b + cells were found in the cortex and striatum of brains from representative PBS-treated animals, the CD11b + cells in the brains of LIF-treated animals showed a more ramified phenotype. Scale bar $=50 \mu \mathrm{m}$. c Western blotting was performed to show levels of CD11b in the ipsilateral and contralateral brain tissue in PBS and LIF-treated rats. There was a significant decrease in the ipsilateral CD11b levels after LIF treatment compared to PBS treatment ( $\left.{ }^{*} p<0.05\right)$. CD11b levels were significantly elevated in the ipsilateral hemispheres of the PBS-treated $\left({ }^{* *} p<0.01\right)$ and LIF-treated $\left({ }^{*} p<0.05\right)$ animals compared to their contralateral counterparts. $n=5-6$ animals per treatment group

production of IFNY after stimulation with concavalin-A [80]. In a subsequent study, human umbilical cord blood cell treatment after MCAO significantly attenuated the migration of pro-inflammatory isolectin-binding monocytes/macrophages into the ischemic brain [20]. Since the PI3K/Akt signaling axis promotes an anti-inflammatory phenotype in microglia/macrophages [81], it is possible that systemic LIF administration reduces inflammation among peripheral leukocytes through is transduction pathway.

\section{Conclusion}

Through this study and previously published manuscripts, this lab has demonstrated that LIF treatment after stroke promotes neuroprotection and recovery through two distinct mechanisms: Akt-dependent upregulation of antioxidant enzymes [46, 47] and modulation of the IL-12 p40/IFN $\gamma / \mathrm{IP}-10$ signaling pathway. Future studies dictate that these studies need to be replicated in aged rodents of both sexes, since several groups have identified sex-specific and age-dependent differences in stroke pathophysiology, specifically concerning the post-stroke immune response [82-86].

This laboratory is currently performing studies to determine the neuroprotective efficacy and anti-inflammatory action of LIF in aged (18 month) male and female rats after stroke. Preliminary results show that LIF exhibits potent anti-inflammatory signaling in the splenocytes of aged female rats after stroke. This study on aged animals also includes the use of flow cytometry to determine whether ischemic conditions alter the expression of LIFR on subpopulations of immune cells after stroke [87]. Although there are antagonists available for LIFR [88], it is very difficult to isolate the specific effects of LIFR after exogenous LIF treatment, since LIFR is also crucial for the signaling of other IL-6 family cytokines [89-91]. Therefore, 


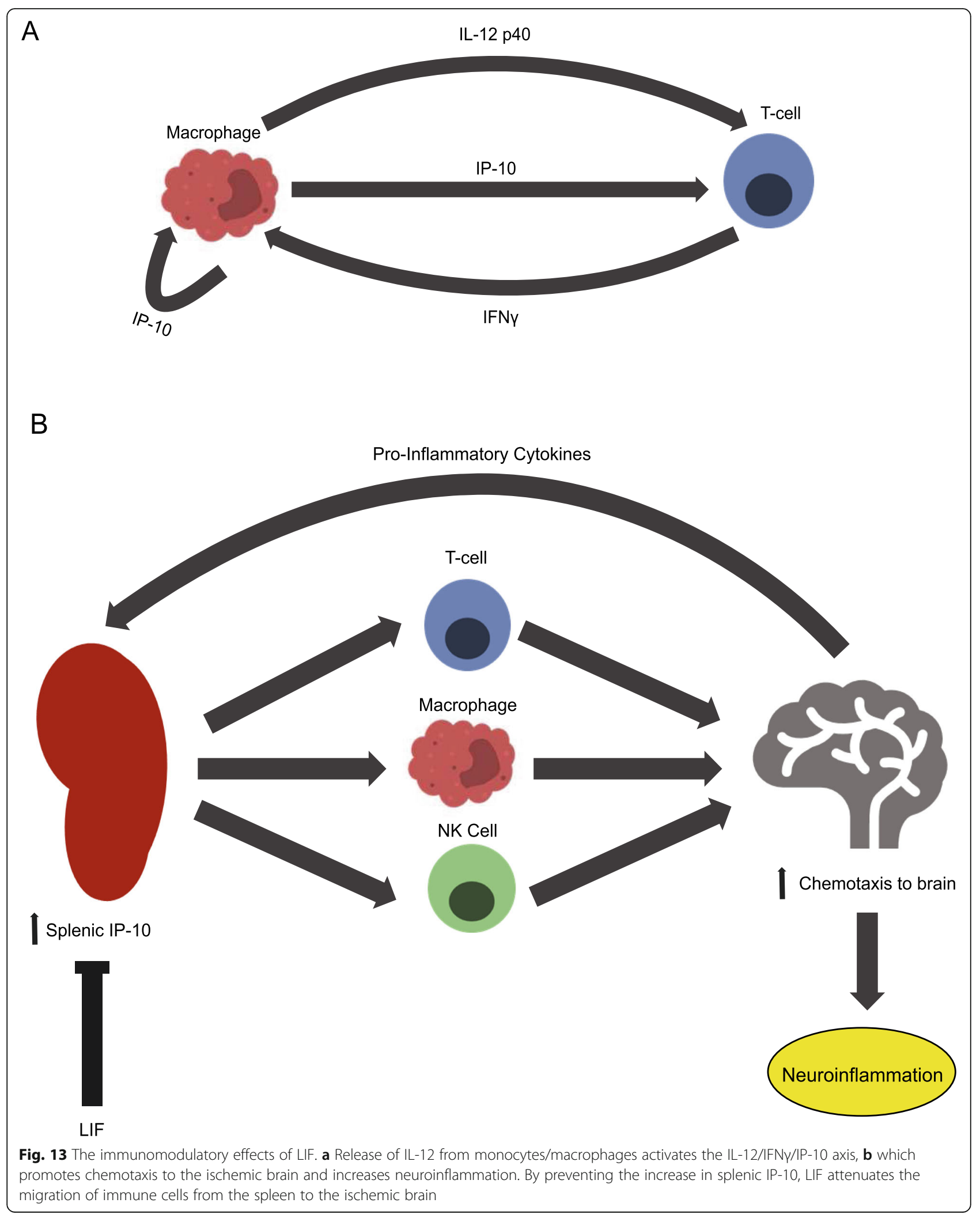


examining expression of LIFR among leukocyte populations might provide further insight into how LIF promotes anti-inflammatory signaling in splenocytes and peripheral blood leukocyte after stroke.

Nevertheless, these data demonstrate the need for new therapeutics that target the peripheral immune response in addition to directly promoting neuroprotection after stroke.

\section{Abbreviations \\ BMDM: Bone marrow-derived macrophage; ELVO: Emergent large vessel occlusion; IFNY: Interferon gamma; IP-10: Interferon Inducible Protein 10; LIF: Leukemia inhibitory factor; MCAO: Middle cerebral artery occlusion; NK: Natural killer; Th1: Type 1 helper T cells; Th17: IL-17+ helper T cells; tPA: Tissue plasminogen activator; Tregs: Regulatory T cells}

\section{Acknowledgements}

The authors would like to acknowledge the Department of Neurology at the University of Kentucky for providing additional startup funding for experiments and equipment. The authors would also like to acknowledge Dr. Phillip Popovich for generously contributing SL929 cells, Dr. Bei Zhang for assisting with BMDM culture, and Ms. Linda Simmerman for assistance with fluorescent microscopy.

\section{Funding}

The work of K.P. is supported by internal funding from the University of Kentucky as well as the following project grants from the National Institute of Neurological Disorders and Stroke: 1R01NS091146-01, 1R56NS091146-01, and 1R21NS078517-01. The work of J.G. is also supported by funding from the National Institute for Neurological Disorders and Stroke (Project 5R01NS091582-03).

\section{Availability of data and materials}

All data generated and analyzed during this study are not publicly available but can be made available from the corresponding author upon request.

\section{Authors' contributions}

$\mathrm{SD}$ and KP designed all experiments for the current study except for the experiments shown in Fig. 7, which were designed, performed, and analyzed by TK and JG. Other experiments were performed and data was collected by SD, LC, TA, CC, and EF. Data analysis and interpretation was performed by SD and LC. Manuscript and figures were prepared by SD and KP. All authors were involved with revising and approving the final draft of the manuscript prior to submission.

\section{Ethics approval and consent to participate}

All animal experiments performed in this study were approved in advance by the Institutional Animal Care and Use Committees at the University of South Florida and the University of Kentucky.

\section{Consent for publication}

Not applicable.

\section{Competing interests}

The authors declare that they have no competing interests.

\section{Publisher's Note}

Springer Nature remains neutral with regard to jurisdictional claims in published maps and institutional affiliations.

\section{Author details}

'Department of Neurology, University of Kentucky, 741 S. Limestone BBSRB B457, Lexington, KY 40536-0905, USA. ²Department of Neuroscience, University of Kentucky, 800 Rose St. Lexington, Lexington, KY 40536, USA. ${ }^{3}$ Department of Physiology, University of Kentucky, 800 Rose St. MS508, Lexington, KY 40536, USA. ${ }^{4}$ Spinal Cord and Brain Injury Repair Center, University of Kentucky, 741 S. Limestone BBSRB B463, Lexington, KY 40536, USA. ${ }^{5}$ Department of Molecular Pharmacology and Physiology, University of
South Florida, 12901 Bruce B. Downs Blvd MDC 8, Tampa, FL 33612, USA. ${ }^{6}$ Department of Molecular Medicine, University of South Florida, 12901 Bruce B. Downs Blvd MDC 7, Tampa, FL 33612, USA.

Received: 6 June 2018 Accepted: 5 October 2018

Published online: 15 October 2018

\section{References}

1. Smith WS, Lev MH, English JD, Camargo EC, Chou M, Johnston SC, Gonzalez G, Schaefer PW, Dillon WP, Koroshetz WJ. Significance of large vessel intracranial occlusion causing acute ischemic stroke and TIA. Stroke. 2009:40: $3834-40$.

2. Lima FO, Furie KL, Silva GS, et al. Prognosis of untreated strokes due to anterior circulation proximal intracranial arterial occlusions detected by use of computed tomography angiography. JAMA Neurol. 2014;71:151-7.

3. Jayaraman MV, Hussain MS, Abruzzo T, Albani B, Albuquerque FC, Alexander MJ, Ansari SA, Arthur AS, Baxter B, Bulsara KR. Embolectomy for stroke with emergent large vessel occlusion (ELVO): report of the Standards and Guidelines Committee of the Society of Neurolnterventional Surgery. J Neurointerventional Surg. 2015;2015:011717 neurintsurg.

4. Campbell BC, Mitchell PJ, Kleinig TJ, Dewey HM, Churilov L, Yassi N, Yan B, Dowling RJ, Parsons MW, Oxley TJ, et al. Endovascular therapy for ischemic stroke with perfusion-imaging selection. N Engl J Med. 2015;372:1009-18.

5. Goyal M, Menon BK, van Zwam WH, Dippel DWJ, Mitchell PJ, Demchuk AM, Dávalos A, Majoie CBLM, van der Lugt A, de Miquel MA, et al. Endovascular thrombectomy after large-vessel ischaemic stroke: a meta-analysis of individual patient data from five randomised trials. Lancet. 2016;387:1723-31.

6. Menon B, Brown S, Almekhlafi M, Dippel D, Campbell B, Mitchell P, Hill M, Demchuk A, Jovin T, Davalos A, et al. 6 Efficacy of endovascular thrombectomy in patients with $\mathrm{M} 2$ segment middle cerebral artery occlusions: meta-analysis of data from the HERMES collaboration. J Neurolnterventional Surg. 2018;10:A139-40.

7. McMeekin P, White P, James MA, Price Cl, Flynn D, Ford GA. Estimating the number of UK stroke patients eligible for endovascular thrombectomy. Eur Stroke J. 2017;2:319-26.

8. Rothstein JD, Dykes-Hoberg M, Pardo CA, Bristol LA, Jin L, Kuncl RW, Kanai $Y$, Hediger MA, Wang Y, Schielke JP. Knockout of glutamate transporters reveals a major role for astroglial transport in excitotoxicity and clearance of glutamate. Neuron. 1996:16:675-86.

9. Bano D, Nicotera P. Ca2+ signals and neuronal death in brain ischemia. Stroke. 2007;38:674-6.

10. Streit W, Graeber M, Kreutzberg G. Functional plasticity of microglia: a review. Glia. 1988;1:301-7.

11. Davalos D, Grutzendler J, Yang G, Kim JV, Zuo Y, Jung S, Littman DR, Dustin $\mathrm{ML}$, Gan WB. ATP mediates rapid microglial response to local brain injury in vivo. Nat Neurosci. 2005;8:752-8.

12. Marsh BJ, Williams-Karnesky RL, Stenzel-Poore MP. Toll-like receptor signaling in endogenous neuroprotection and stroke. Neuroscience. 2009; 158:1007-20.

13. Patel AR, Ritzel R, McCullough LD, Liu F. Microglia and ischemic stroke: a double-edged sword. Internatl J of Phys Pathophys Pharm. 2013;5:73-90.

14. Clark AW, Krekoski CA, Bou SS, Chapman KR, Edwards DR. Increased gelatinase a (MMP-2) and gelatinase B (MMP-9) activities in human brain after focal ischemia. Neurosci Lett. 1997;238:53-6.

15. Akopov SE, Simonian NA, Grigorian GS. Dynamics of polymorphonuclear leukocyte accumulation in acute cerebral infarction and their correlation with brain tissue damage. Stroke. 1996;27:1739-43.

16. Barone FC, Feuerstein GZ. Inflammatory mediators and stroke: new opportunities for novel therapeutics. J Cereb Blood Flow Metab. 1999;19: 819-34.

17. Vendrame M, Cassady J, Newcomb J, Butler T, Pennypacker KR, Zigova T, Sanberg CD, Sanberg PR, Willing AE. Infusion of human umbilical cord blood cells in a rat model of stroke dose-dependently rescues behavioral deficits and reduces infarct volume. Stroke. 2004;35:2390-5.

18. Hurn PD, Subramanian $S$, Parker SM, Afentoulis ME, Kaler $L$, Vandenbark AA, Offner H. T- and B-cell-deficient mice with experimental stroke have reduced lesion size and inflammation. J Cereb Blood Flow Metab. 2007;27: 1798-805.

19. ladecola C, Anrather J. The immunology of stroke: from mechanisms to translation. Nat Med. 2011;17:796-808. 
20. Leonardo CC, Hall AA, Collier LA, Ajmo CTJ, Willing AE, Pennypacker KR. Human umbilical cord blood cell therapy blocks the morphological change and recruitment of CD-11b-expressing isolectin-binding proinflammatory cells after middle cerebral artery occlusion. J Neurosci Res. 2010;88:1213-22.

21. Leonardo CC, Musso J, Das M, Rowe DD, Collier LA, Mohapatra S, Pennypacker KR. CCL20 is associated with neurodegeneration following experimental traumatic brain injury and promotes cellular toxicity in vitro. Transl Stroke Res. 2012;3:357-63.

22. Myers MG, Norris JW, Hachniski VC, Sole MJ. Plasma norepinephrine in stroke. Stroke. 1981;12:200-4.

23. Ajmo CT Jr, Collier LA, Leonardo CC, Hall AA, Green SM, Womble TA, Cuevas J, Willing AE, Pennypacker KR. Blockade of adrenoreceptors inhibits the splenic response to stroke. Exp Neurol. 2009;218(1):47-55.

24. Chen H, Chopp M, Zhang RL, Bodzin G, Chen Q, Rusche JR, Todd RF 3rd Anti-CD11b monoclonal antibody reduces ischemic cell damage after transient focal cerebral ischemia in rat. Ann Neurol. 1994;35:458-63.

25. Vendrame M, Gemma C, De Mesquita D, Collier L, Bickford PC, Sanberg CD, Sanberg PR, Pennypacker KR, Willing AE. Anti-inflammatory effects of human cord blood cells in a rat model of stroke. Stem Cells Dev. 2005;14:595-604.

26. Ajmo CT Jr, Vernon DO, Collier L, Hall AA, Garbuzova-Davis S, Willing A, Pennypacker KR. The spleen contributes to stroke-induced neurodegeneration. J Neurosci Res. 2008;86:2227-34.

27. Seifert HA, Hall AA, Chapman CB, Collier LA, Willing AE, Pennypacker KR. A transient decrease in spleen size following stroke corresponds to splenocyte release into systemic circulation. J Neuroimmune Pharm. 2012;7:1017-24.

28. Schoenborn JR, Wilson CB. Regulation of interferon- $\gamma$ during innate and adaptive immune responses. In: Advances in Immunology. Boston: Academic Press; 2007:96:41-101.

29. Mosser DM, Edwards JP. Exploring the full spectrum of macrophage activation. Nature Rev Immuno. 2008;8:958-69.

30. Seifert HA, Collier LA, Chapman CB, Benkovic SA, Willing AE, Pennypacker KR. Pro-inflammatory interferon gamma signaling is directly associated with stroke induced neurodegeneration. J Neuroimmune Pharmacol. 2014;9:679-89.

31. Vahidy FS, Parsha KN, Rahbar MH, Lee MK, Bui TT, Nguyen C, Barreto AD, Bambhroliya AB, Sahota P, Yang B, et al. Acute splenic responses in patients with ischemic stroke and intracerebral hemorrhage. J Cereb Blood Flow Met. 2015;36(6):1012-21.

32. Vahidy FS, Rahbar MH, Lee M, Parsha KN, Sahota P, Nguyen CB, Bui T, Barreto AD, Bambhroliya AB, Aronowski J, et al. Spleen contraction in patients with ischemic stroke and brain hemorrhage: validating anima studies. Stroke. 2015;46:A166

33. Zha A, Vahidy F, Randhawa J, Parsha K, Bui T, Aronowski J, Savitz SI. Association between splenic contraction and the systemic inflammatory response after acute ischemic stroke varies with age and race. Transl Stroke Res. 2018;9(5):484-92.

34. Kurek JB, Radford AJ, Crump DE, Bower JJ, Feeney SJ, Austin L, Byrne E. LIF (AM424), a promising growth factor for the treatment of ALS. J Neurol Sci. 1998;160(1):S106-13.

35. Azari MF, Galle A, Lopes EC, Kurek J, Cheema SS. Leukemia inhibitory factor by systemic administration rescues spinal motor neurons in the SOD1 G93A murine model of familial amyotrophic lateral sclerosis. Brain Res. 2001;922:144-7.

36. Butzkueven $H$, Zhang JG, Soilu-Hanninen M, Hochrein H, Chionh F, Shipham KA, Emery B, Turnley AM, Petratos S, Ernst M, et al. LIF receptor signaling limits immune-mediated demyelination by enhancing oligodendrocyte survival. Nat Med. 2002:8:613-9.

37. Butzkueven H, Emery B, Cipriani T, Marriott MP, Kilpatrick TJ. Endogenous leukemia inhibitory factor production limits autoimmune demyelination and oligodendrocyte loss. Glia. 2006;53:696-703.

38. Linker RA, Kruse N, Israel S, Wei T, Seubert S, Hombach A, Holtmann B, Luhder F, Ransohoff RM, Sendtner M. Leukemia inhibitory factor deficiency modulates the immune response and limits autoimmune demyelination: a new role for neurotrophic cytokines in neuroinflammation. J Immunol. 2008; 180:2204-13.

39. Marriott MP, Emery B, Cate HS, Binder MD, Kemper D, Wu Q, Kolbe $S$, Gordon IR, Wang H, Egan $\mathrm{G}$, et al. Leukemia inhibitory factor signaling modulates both central nervous system demyelination and myelin repair. Glia. 2008:56:686-98.

40. Slaets H, Dumont D, Vanderlocht J, Noben JP, Leprince P, Robben J, Hendriks J, Stinissen P, Hellings N. Leukemia inhibitory factor induces an antiapoptotic response in oligodendrocytes through Akt-phosphorylation and up-regulation of 14-3-3. Proteomics. 2008;8:1237-47.
41. Rittchen S, Boyd A, Burns A, Park J, Fahmy TM, Metcalfe S, Williams A. Myelin repair in vivo is increased by targeting oligodendrocyte precursor cells with nanoparticles encapsulating leukaemia inhibitory factor (LIF). Biomaterials. 2015;56:78-85.

42. Janssens K, Van den Haute C, Baekelandt V, Lucas S, van Horssen J, Somers V, Van Wijmeersch B, Stinissen P, Hendriks JJ, Slaets H, Hellings N. Leukemia inhibitory factor tips the immune balance towards regulatory $T$ cells in multiple sclerosis. Brain Behav Immun. 2015;45:180-8.

43. Kerr BJ, Patterson PH. Leukemia inhibitory factor promotes oligodendrocyte survival after spinal cord injury. Glia. 2005;51:73-9.

44. Azari MF, Profyris C, Karnezis T, Bernard CC, Small DH, Cheema SS, Ozturk E, Hatzinisiriou I, Petratos S. Leukemia inhibitory factor arrests oligodendrocyte death and demyelination in spinal cord injury. J Neuropathol Exp Neurol. 2006;65:914-29.

45. Suzuki S, Yamashita T, Tanaka K, Hattori H, Sawamoto K, Okano H, Suzuki N. Activation of cytokine signaling through leukemia inhibitory factor receptor (LIFR)/gp130 attenuates ischemic brain injury in rats. J Cereb Blood Flow Metab. 2005;25:685-93.

46. Rowe DR, Collier LA, Seifert HA, Chapman CB, Leonardo CC, Willing AE, Pennypacker KR. Leukemia inhibitory factor promotes functional recovery and oligodendrocyte survival in rat models of focal ischemia. Eur J Neurosci. 2014:40:3111-9.

47. Davis SM, Collier LA, Leonardo CC, Seifert HA, Ajmo CT, Pennypacker KR. Leukemia inhibitory factor protects neurons from ischemic damage via upregulation of superoxide dismutase 3. Mol Neurobiol. 2017;54:608-22.

48. Rowe D: Secreted factors from human umbilical cord blood cells protect oligodendrocytes from ischemic insult. 2011.

49. Janssens $\mathrm{K}$, Slaets $\mathrm{H}$, Hellings $\mathrm{N}$. Immunomodulatory properties of the IL-6 cytokine family in multiple sclerosis. Annals N Y Acad Scie. 2015;1351:52-60.

50. Duluc D, Delneste $Y$, Tan F, Moles MP, Grimaud L, Lenoir J, Preisser L, Anegon I, Catala L, Ifrah N, et al. Tumor-associated leukemia inhibitory factor and IL-6 skew monocyte differentiation into tumor-associated macrophagelike cells. Blood. 2007;110:4319-30.

51. Merrill JE, Ignarro LJ, Sherman MP, Melinek J, Lane TE. Microglial cell cytotoxicity of oligodendrocytes is mediated through nitric oxide. J Immunol. 1993:151:2132-41.

52. Ajmo CT Jr, Vernon DO, Collier L, Pennypacker KR, Cuevas J. Sigma receptor activation reduces infarct size at 24 hours after permanent middle cerebral artery occlusion in rats. Curr Neurovasc Res. 2006;3:89-98.

53. Seifert HA, Leonardo CC, Hall AA, Rowe DD, Collier LA, Benkovic SA, Willing $A E$, Pennypacker KR. The spleen contributes to stroke induced neurodegeneration through interferon gamma signaling. Metab Brain Dis. 2012:27:131-41.

54. Hall AA, Guyer AG, Leonardo CC, Ajmo CT Jr, Collier LA, Willing AE, Pennypacker KR. Human umbilical cord blood cells directly suppress ischemic oligodendrocyte cell death. J Neurosci Res. 2009;87:333-41.

55. Gensel JC, Nakamura S, Guan Z, van Rooijen N, Ankeny DP, Popovich PG. Macrophages promote axon regeneration with concurrent neurotoxicity. $J$ Neurosci. 2009;29:3956-68

56. Gensel JC, Zhang B. Macrophage activation and its role in repair and pathology after spinal cord injury. Brain Res. 1619;2015:1-11.

57. Zhang B, Bailey WM, Braun KJ, Gensel JC. Age decreases macrophage IL-10 expression: implications for functional recovery and tissue repair in spinal cord injury. Exp Neurol. 2015;273:83-91.

58. Burgess AW, Metcalf D, Kozka I, Simpson R, Vairo G, Hamilton J, Nice E. Purification of two forms of colony-stimulating factor from mouse L-cellconditioned medium. J Biol Chem. 1985;260:16004-11.

59. Kigerl KA, Gensel JC, Ankeny DP, Alexander JK, Donnelly DJ, Popovich PG. Identification of two distinct macrophage subsets with divergent effects causing either neurotoxicity or regeneration in the injured mouse spinal cord. J Neurosci. 2009:29:13435-44.

60. Offner $\mathrm{H}$, Subramanian $\mathrm{S}$, Parker SM, Afentoulis ME, Vandenbark AA, Hurn PD. Experimental stroke induces massive, rapid activation of the peripheral immune system. J Cereb Blood Flow Metab. 2006;26:654-65.

61. Blanchard F, Duplomb L, Wang Y, Robledo O, Kinzie E, Pitard V, Godard A, Jacques Y, Baumann H. Stimulation of leukemia inhibitory factor receptor degradation by extracellular signal-regulated kinase. J Biol Chem. 2000;275:28793-801.

62. Woods AM, Mcllmoil CJ, Rankin EN, Packer AA, Stevens JC, Macievic JA, Brown $A B$, Porter JP, Judd AM. Leukemia inhibitory factor protein and receptors are expressed in the bovine adrenal cortex and increase cortisol and decrease adrenal androgen release. Domest Anim Endocrinol. 2008;35:217-30. 
63. Schulze J, Vogelgesang A, Dressel A. Catecholamines, steroids and immune alterations in ischemic stroke and other acute diseases. Aging Dis. 2014;5:327

64. Heufler C, Koch F, Stanzl U, Topar G, Wysocka M, Trinchieri G, Enk A, Steinman RM, Romani N, Schuler G. Interleukin-12 is produced by dendritic cells and mediates $T$ helper 1 development as well as interferon- $\gamma$ production by T helper 1 cells. Eur J Immunol. 1996;26:659-68.

65. Zhu J, Paul WE. CD4 T cells: fates, functions, and faults. Blood. 2008;112: 1557-69.

66. Konoeda F, Shichita T, Yoshida H, Sugiyama Y, Muto G, Hasegawa E, Morita $\mathrm{R}$, Suzuki N, Yoshimura A. Therapeutic effect of IL-12/23 and their signaling pathway blockade on brain ischemia model. Biochem Biophys Res Commun. 2010;402:500-6.

67. D'andrea A, Aste-Amezaga M, Valiante NM, Ma X, Kubin M, Trinchieri G. Interleukin 10 (IL-10) inhibits human lymphocyte interferon gammaproduction by suppressing natural killer cell stimulatory factor/IL-12 synthesis in accessory cells. J Exp Med. 1993;178:1041-8.

68. te Velde AA, Huijbens R, Heije K, de Vries JE, Figdor CG. Interleukin-4 (IL-4) inhibits secretion of IL-1 beta, tumor necrosis factor alpha, and IL- 6 by human monocytes. Blood. 1990;76:1392-7.

69. Neuner P, Urbanski A, Trautinger F, Möller A, Kirnbauer R, Kapp A, Schöpf E, Schwarz T, Luger TA. Increased IL-6 production by monocytes and keratinocytes in patients with psoriasis. J Investig Dermatol. 1991;97:27-33.

70. Luster AD. The role of chemokines in linking innate and adaptive immunity. Curr Opin Immunol. 2002;14:129-35.

71. Arumugam TV, Granger DN, Mattson MP. Stroke and T-cells. NeuroMolecular Med. 2005;7:229-42.

72. Yilmaz G, Arumugam TV, Stokes KY, Granger DN. Role of T lymphocytes and interferon- $\gamma$ in ischemic stroke. Circulation. 2006;113:2105-12.

73. Agostini C, Calabrese F, Rea F, Facco M, Tosoni A, Loy M, Binotto G, Valente M, Trentin L, Semenzato G. CXCr3 and its ligand CXCL10 are expressed by inflammatory cells infiltrating lung allografts and mediate chemotaxis of $T$ cells at sites of rejection. Am J Pathol. 2001;158:1703-11.

74. Loetscher P, Pellegrino A, Gong JH, Mattioli I, Loetscher M, Bardi G, Baggiolini M, Clark-Lewis I. The ligands of CXC chemokine receptor 3, I-TAC, Mig, and IP10, are natural antagonists for CCR3. J Biol Chem. 2001;276:2986-91.

75. Offner $\mathrm{H}$, Subramanian S, Parker SM, Wang C, Afentoulis ME, Lewis A, Vandenbark AA, Hurn PD. Splenic atrophy in experimental stroke is accompanied by increased regulatory $T$ cells and circulating macrophages. Immunol. 2006;176:6523-31.

76. Streit WJ, Kreutzberg GW. Lectin binding by resting and reactive microglia. J Neurocytol. 1987;16:249-60.

77. Zhang Y, Gao Z, Wang D, Zhang T, Sun B, Mu L, Wang J, Liu Y, Kong Q, Liu $X$, et al. Accumulation of natural killer cells in ischemic brain tissues and the chemotactic effect of IP-10. J Neuroinflammation. 2014;11:79.

78. Shahaduzzaman M, Mehta V, Golden JE, Rowe DD, Green S, Tadinada R, Foran E, Sanberg PR, Pennypacker KR, Willing AE. Human umbilical cord blood cells induce neuroprotective change in gene expression profile in neurons afterilschemia through activation of Akt pathway. Cell Transplant. 2015; (Epub ahead of press).

79. Rowe DD, Leonardo CC, Recio JA, Collier LA, Willing AE, Pennypacker KR Human umbilical cord blood cells protect oligodendrocytes from brain ischemia through Akt signal transduction. J Biol Chem. 2012;287:4177-87.

80. Vendrame M, Gemma C, Pennypacker KR, Bickford PC, Davis Sanberg C, Sanberg PR, Willing AE. Cord blood rescues stroke-induced changes in splenocyte phenotype and function. Exp Neurol. 2006;199:191-200.

81. Wang G, Shi Y, Jiang X, Leak RK, Hu X, Wu Y, Pu H, Li W-W, Tang B, Wang Y. HDAC inhibition prevents white matter injury by modulating microglia/ macrophage polarization through the GSK3ß/PTEN/Akt axis. Proc Natl Acad Sci. 2015;112:2853-8

82. Dotson AL, Wang J, Saugstad J, Murphy SJ, Offner H. Splenectomy reduces infarct volume and neuroinflammation in male but not female mice in experimental stroke. J Neuroimmunol. 2015;278:289-98.

83. Bodhankar S, Lapato A, Chen Y, Vandenbark AA, Saugstad JA, Offner H. Role for microglia in sex differences after ischemic stroke: importance of $M 2$. Metab Brain Dis. 2015;30:1515-29.

84. Dotson AL, Wang J, Chen Y, Manning D, Nguyen H, Saugstad JA, Offner $H$. Sex differences and the role of PPAR alpha in experimental stroke. Metab Brain Dis. 2016;31:539-47.

85. Dotson $\mathrm{AL}$, Offner $\mathrm{H}$. Sex differences in the immune response to experimental stroke: implications for translational research. J Neurosci Res. 2017;95:437-46.
86. Bravo-Alegria J, McCullough LD, Liu F. Sex differences in stroke across the lifespan: the role of T lymphocytes. Neurochem Int. 2017;107:127-37.

87. Davis SM, Collier LA, Martha SR, Powell DK, Pennypacker KR. Abstract WMP77: anti-inflammatory signaling by leukemia inhibitory factor is suppressed in aged animals after stroke. Am Heart Assoc. 2018.

88. Mohamet L, Heath JK, Kimber S. Determining the LIF-sensitive period for implantation using a LIF-receptor antagonist. Reproduction. 2009;138:827-36.

89. Ip NY, Nye SH, Boulton TG, Davis SM, Taga T, Li Y, Birren SJ, Yasukawa K, Kishimoto T, Anderson DJ, et al. CNTF and LIF act on neuronal cells via shared signaling pathways that involve the IL-6 signal transducing receptor component gp130. Cell. 1992;69:1121-32.

90. Arce $V$, Garces A, de Bovis B, Filippi $P$, Henderson C, Pettmann B, deLapeyrière O. Cardiotrophin-1 requires LIFRß to promote survival of mouse motoneurons purified by a novel technique. J Neurosci Res. 1999;55:119-26.

91. Blanchard F, Wang Y, Kinzie E, Duplomb L, Godard A, Baumann H. Oncostatin M regulates the synthesis and turnover of gp130, leukemia inhibitory factor receptor alpha, and oncostatin $\mathrm{M}$ receptor beta by distinct mechanisms. J Biol Chem. 2001;276:47038-45.

\section{Ready to submit your research? Choose BMC and benefit from:}

- fast, convenient online submission

- thorough peer review by experienced researchers in your field

- rapid publication on acceptance

- support for research data, including large and complex data types

- gold Open Access which fosters wider collaboration and increased citations

- maximum visibility for your research: over $100 \mathrm{M}$ website views per year

At $\mathrm{BMC}$, research is always in progress.

Learn more biomedcentral.com/submissions 